\title{
Article
}

\section{Synchrotron-Based Fourier-Transform Infrared Micro-Spectroscopy (SR-FTIRM) Fingerprint of the Small Anionic Molecule Cobaltabis(dicarbollide) Uptake in Glioma Stem Cells}

\author{
Miquel Nuez-Martínez ${ }^{1,+}$, Leire Pedrosa ${ }^{2,+}{ }^{(\mathbb{D}}$, Immaculada Martinez-Rovira ${ }^{3,4}\left(\mathbb{D}\right.$, Ibraheem Yousef ${ }^{4}$ (D), \\ Diouldé Diao $^{2}$, Francesc Teixidor ${ }^{1}$, Elisabetta Stanzani ${ }^{5} \mathbb{D}$, Fina Martínez-Soler ${ }^{6} \mathbb{D}$, Avelina Tortosa ${ }^{6} \mathbb{D}$, \\ Àngels Sierra ${ }^{2, * \mathbb{D}}$, José Juan Gonzalez ${ }^{2}$ and Clara Viñas ${ }^{1, * \mathbb{D}}$
}

check for
updates

Citation: Nuez-Martínez, M.;

Pedrosa, L.; Martinez-Rovira, I.;

Yousef, I.; Diao, D.; Teixidor, F.;

Stanzani, E.; Martínez-Soler, F.;

Tortosa, A.; Sierra, À.; et al.

Synchrotron-Based

Fourier-Transform Infrared

Micro-Spectroscopy (SR-FTIRM)

Fingerprint of the Small Anionic

Molecule Cobaltabis(dicarbollide)

Uptake in Glioma Stem Cells. Int. J.

Mol. Sci. 2021, 22, 9937. https://

doi.org/10.3390/ijms22189937

Academic Editor: Maria

Alexandra Brito

Received: 30 July 2021

Accepted: 10 September 2021

Published: 14 September 2021

Publisher's Note: MDPI stays neutra with regard to jurisdictional claims in published maps and institutional affiliations.

Copyright: (c) 2021 by the authors. Licensee MDPI, Basel, Switzerland. This article is an open access article distributed under the terms and conditions of the Creative Commons Attribution (CC BY) license (https:// creativecommons.org/licenses/by/ $4.0 /)$.
1 Institut de Ciència de Materials de Barcelona, ICMAB-CSIC, Campus Universitat Autònoma de Barcelona, 08193 Bellaterra, Spain; mnuez@icmab.es (M.N.-M.); teixidor@icmab.es (F.T.)

2 Laboratory of Experimental Oncological Neurosurgery, Neurosurgery Service, Hospital Clinic de Barcelona-FCRB, 08036 Barcelona, Spain; lepedrosa@clinic.cat (L.P.); dioulde.dg@gmail.com (D.D.); jjgonzal@clinic.cat (J.J.G.)

3 Ionizing Radiation Research Group (GRRI), Physics Department, Universitat Autònoma de Barcelona (UAB), Avinguda de 1'Eix Central, Edifici C. Campus de la UAB, 08193 Cerdanyola del Vallès, Spain; Immaculada.Martinez@uab.cat

4 ALBA-CELLS Synchrotron, MIRAS Beamline, Carrer de la Llum 2-26, 08290 Cerdanyola del Vallès, Spain; iyousef@cells.es

5 Laboratory of Pharmacology and Brain Pathology, IRCCS Humanitas Research Hospital, 20089 Rozzano, Italy; stanzani.elisabetta@gmail.com

6 Apoptosis and Cancer Unit, Department of Physiological Sciences, IDIBELL, Faculty of Medicine and Health Sciences, Universitat de Barcelona, 08907 L'Hospitalet del Llobregat, Spain; finamartinez@ub.edu (F.M.-S.); atortosa@ub.edu (A.T.)

* Correspondence: masierra@clinic.cat (À.S.); clara@icmab.es (C.V.)

$\dagger \quad$ The authors contributed equally to the work.

Abstract: The anionic cobaltabis (dicarbollide) $\left[3,3^{\prime}-\mathrm{Co}\left(1,2-\mathrm{C}_{2} \mathrm{~B}_{9} \mathrm{H}_{11}\right)_{2}\right]^{-},{ }^{-}$o-COSAN $]^{-}$, is the most studied icosahedral metallacarborane. The sodium salts of $[o-\mathrm{COSAN}]^{-}$could be an ideal candidate for the anti-cancer treatment Boron Neutron Capture Therapy (BNCT) as it possesses the ability to readily cross biological membranes thereby producing cell cycle arrest in cancer cells. BNCT is a cancer therapy based on the potential of ${ }^{10} \mathrm{~B}$ atoms to produce $\alpha$ particles that cross tissues in which the ${ }^{10} \mathrm{~B}$ is accumulated without damaging the surrounding healthy tissues, after being irradiated with low energy thermal neutrons. Since $\mathrm{Na}[\mathrm{o}-\mathrm{COSAN}]$ displays a strong and characteristic $v(\mathrm{~B}-\mathrm{H})$ frequency in the infrared range $2.600-2.500 \mathrm{~cm}^{-1}$, we studied the uptake of $\mathrm{Na}$ [o-COSAN] followed by its interaction with biomolecules and its cellular biodistribution in two different glioma initiating cells (GICs), mesenchymal and proneural respectively, by using Synchrotron RadiationFourier Transform Infrared (FTIR) micro-spectroscopy (SR-FTIRM) facilities at the MIRAS Beamline of ALBA synchrotron light source. The spectroscopic data analysis from the bands in the regions of DNA, proteins, and lipids permitted to suggest that after its cellular uptake, $\mathrm{Na}[0-\mathrm{COSAN}]$ strongly interacts with DNA strings, modifies proteins secondary structure and also leads to lipid saturation. The mapping suggests the nuclear localization of $[o-\mathrm{COSAN}]^{-}$, which according to reported Monte Carlo simulations may result in a more efficient cell-killing effect compared to that in a uniform distribution within the entire cell. In conclusion, we show pieces of evidence that at low doses, $[o-\mathrm{COSAN}]^{-}$translocates GIC cells' membranes and it alters the physiology of the cells, suggesting that $\mathrm{Na}[o-\mathrm{COSAN}]$ is a promising agent to BNCT for glioblastoma cells.

Keywords: boron neutron capture therapy; cobaltabis(dicarbollide); DNA interactions; glioblastoma; glioma initiating cells; inorganic small molecules; lipid saturation; SR-FTIRM 


\section{Introduction}

Glioblastoma (GBM) is the most frequent and aggressive primary tumor in the central nervous system (CNS). Owing to their fast-clinical course and uniform lethality after standard treatment—surgical resection followed by chemoradiotherapy regimen [1] — most patients with GBM have a median survival of approximately 15 months from diagnosis [2] because almost all GBMs develop resistance to therapy and recurrence $[3,4]$.

In vitro and in vivo observations give strength to the existence of human glioblastoma cell subpopulations with the ability to initiate tumors, when injected orthotopically into mice $[5,6]$. These glioma initiating cells (GICs) express stemness-related markers and perform cellular niches supported by the tumor microenvironment recapitulating cellular heterogeneity, chemo- and radio-resistance [7].

Adult GBMs can be classified according to their gene expression and epigenetic profiles into four different subtypes: glioma-CpG island methylator phenotype (G-CIMP ${ }^{+}$) and three non-G-CIMP (G-CIMP- ${ }^{-}$subtypes termed as proneural (PN), classical (CL), and mesenchymal (MES) [8-10]. G-CIMP ${ }^{+}$GBMs are associated with somatic mutations in the IDH1 or IDH2 genes and show a more favorable prognosis, whereas non-G-CIMP GBM patients have the poorest prognosis [8]. Non-G-CIMP GBMs display elevated transcriptional plasticity and have an intrinsic ability to transition from PN to MES phenotype, more aggressive, with a higher likelihood of recurrence [11] and therapy resistance [4,12].

In the last decade, boron neutron capture therapy (BNCT), a tumor-selective particle radiation therapy, emerges as an alternative treatment, when chemotherapy and radiation fell short [13]. Indeed, BNCT has been used to treat recurrent or newly diagnosed highgrade glioma showing prolonged survival about the control cohort [14]. This non-invasive binary cancer radiotherapeutic modality is based on the nuclear capture and fission reactions that occur when the stable isotope ${ }^{10} \mathrm{~B}$, a constituent of natural elemental boron, is irradiated with low-energy epithermal neutrons $(10,000 \mathrm{eV})$ to produce high linear-energy transfer $\alpha$ particles $[15,16]$, which locally deposit the energy in tissues and thus, enhances the dose in tumor cells.

There are quite a few strict pre-requisites before employing boron drugs for BNCT applications regarding their toxicity, solubility, and on their ability to reach the required amount of ${ }^{10} \mathrm{~B}$ inside the target cells. It is accepted that $20-30 \mu \mathrm{g}$ of ${ }^{10} \mathrm{~B}$ per gram of tumor is required for ensuring the therapeutic efficiency of BNCT [17]. With the development of new synthetic techniques and increased awareness of the biochemical requirements needed for effective boron-containing agents, several new neutral [18-21] and anionic metallacarborane compounds have been developed [22-24]. Among them, the anionic cobaltabis(dicarbollide) $\left[3,3^{\prime}-\mathrm{Co}\left(1,2-\mathrm{C}_{2} \mathrm{~B}_{9} \mathrm{H}_{11}\right)_{2}\right]^{-},[0-\mathrm{COSAN}]^{-}$, in which $\mathrm{Co}^{3+}$ ion is sandwiched between two $\left[7,8-\mathrm{C}_{2} \mathrm{~B}_{9} \mathrm{H}_{11}\right]^{2-}$ ligands is the most studied icosahedral metallacarborane. The abiotic icosahedral anionic $[0-\mathrm{COSAN}]^{-}$cluster, which incorporates the redox properties of the metal, is thermally and chemically stable [24] with the negative charge spread all over the molecule [25], and possesses many possibilities to produce hydrogen and dihydrogen bonds $\left(\mathrm{C}_{\mathrm{c}}-\mathrm{H} \cdots \mathrm{O}\right.$ and $\mathrm{C}_{\mathrm{c}}-\mathrm{H} \cdots \mathrm{H}-\mathrm{B}$ or $\mathrm{N}-\mathrm{H} \cdots \mathrm{H}-\mathrm{B}$, respectively; $\mathrm{C}_{\mathrm{c}}$ represents the $\mathrm{C}_{\text {cluster }}$ atoms). The hydrogen and dihydrogen bonds have been proven to participate in its self-assembly [26-28], water solubility [29], as well as in its micelles and vesicles formation [29-33].

Recently, Synchrotron-based Fourier-transform infrared micro-spectroscopy (SR-FTIRM) has developed into a novel and powerful biomedical tool that can reveal subtle alterations in the conformation of key molecular structures of cells (DNA, proteins, and lipids) providing rapid, non-destructive, and clinically relevant diagnostic information [34]. SR-FTIRM, which couples IR spectrometer with single element detectors and optical microscope, has become a valuable technique for analyzing the vibrational motions on a microscopic scale of biomolecules [35]. This technique allows in situ structure determination of the most important biomolecules (nucleic acids, proteins, lipids) in the chosen sub-cellular compartments [36]. The higher spatial resolution and spectral quality, in comparison with the "classic" Fouriertransform infrared microscopy, can be attributed to the synchrotron IR source, which is 
100-1000 times brighter than a conventional thermal source for IR spectroscopy [37]. The higher brightness (flux density) of the synchrotron that is due to the small effective source and its very narrow emittance, allows the analysis of smaller regions with an acceptable signal-to-noise ratio, and the spatial resolution reaches the diffraction limit $(\lambda / 2)[34,38,39]$. The structure of biomolecules inside cells can be probed with a sub-cellular resolution thanks to the high spatial resolution of the SR-FTIR technique, which generates many data. The IR spectra collected of hundreds of cells need subsequently the application of multivariate statistical methods for efficient data analysis. The principal component analysis (PCA) is a powerful method for analyzing the large amount of spectral data set for the presence of discriminant features that classify the spectra [40,41].

Having performed experiments in a round-bottom flask on a chemical scale, which showed that $[0-\mathrm{COSAN}]^{-}$and some of its halogenated derivatives interact with biomolecules (carbohydrates [42], proteins [43] and DNA [44]), we have wanted to observe these interactions in vitro experiments by changing the round-bottom flask to a cell and the solutions to the physiological components of the cell. In addition, the previous studies at the chemical scale were done individually, whereas the present study incorporates the effect of all the interacting biomolecules in a cell. Furthermore, we wanted to go a step ahead to understand if this small anion modifies some of the biomolecules and in which of the cells' organelles the $[o-\mathrm{COSAN}]^{-}$concentrates. With this in mind, in this study, we show that SR-FTIRM can be applied to the detection of boron clusters (boranes, carboranes, and metallacarboranes) interacting with biomolecules inside cells and their location into the cells' organelle after their cellular uptake. This is possible because these compounds' families display a strong and characteristic $v$ B-H frequency in the infrared range $2.600-2.500 \mathrm{~cm}^{-1}$ in which no other frequencies of organic compounds appear. With this objective, we studied the uptake of the sodium salt of cobaltabis(dicarbollide), [Na.2.5 $\left.\mathrm{H}_{2} \mathrm{O}\right]\left[3,3^{\prime}-\mathrm{Co}\left(1,2-\mathrm{C}_{2} \mathrm{~B}_{9} \mathrm{H}_{11}\right)_{2}\right]$, abbreviated as $\mathrm{Na}$ [o-COSAN], in two different phenotypes of glioma initiating cells (GICs), mesenchymaland proneural-GICs, using SR-FTIR micro-spectroscopy to analyze where the agent is located into the cells after their cellular uptake.

Infrared micro-spectroscopy has been used to investigate many phenomena in biology, but in this work we demonstrate for the first time that it can differentiate the two phenotypes of glioma initiating cells (GICs), mesenchymal and proneural GICs, mainly by DNA spectra, protein conformation and lipids components, which were differently modified by $\mathrm{Na}[o-C O S A N]$. Interestingly, specific changes in lipid $2966 \mathrm{~cm}^{-1}$ and $2922 \mathrm{~cm}^{-1}$ frequencies are induced in radio resistant mesenchymal cells PG88, the most efficient in capturing the compound. Although more experiments are needed including representative GICs from glioblastoma phenotypes, these results suggest that SR-FTIRM is useful to acquire a drug and radio-resistance profiling of glioblastoma cells. Moreover, the high uptake of $\mathrm{Na}[o-\mathrm{COSAN}]$ with rapid clearance might fulfil the requirements of boron-containing agents. Furthermore, we also pioneer that SR-FTIRM can be of great interest for BNCT studies. The vast majority of compounds tested for BNCT contain the B-H bond and the IR frequency corresponding to this bond appears in an area of the spectrum where no other signal is observed, thus leaving conclusive evidence of its presence in the tumor or healthy cells under study. This work is therefore dedicated to testing the possibilities of this spectroscopy to study the behavior of a metallacarborane both in its permeation process into the cell and in its irregular distribution in the cell depending on the composition of the site, be it DNA, proteins or lipids.

\section{Results and Discussion}

\section{1. o-Cobaltabis(Dicarbollide), [o-COSAN]- Uptake Induces Glioma Initiating Cells (GICs) Phenotypic Changes}

Analogous to whole tumors and according to GBM-subtype, glioblastoma isolated tumor cell produces tumorspheres enriched in glioma stem-like initiating cells (GICs) with specific phenotypes (Figure 1). Since previous studies indicated that $\mathrm{Na}$ [o-COSAN] enters and accumulates into glioma U87 cells [45], which can be detected by one absorption band 
$\lambda_{\max }$ at $282 \mathrm{~nm}\left(\varepsilon \approx 30.000 \mathrm{~cm}^{-1} \mathrm{~mol}^{-1}\right)$ in the UV-Visible spectra, we analyzed $\mathrm{Na}[o-$ COSAN] uptake in GICs from two different glioblastoma subtypes: proneural-GIC (GIC7) and a mesenchymal-GIC (PG88), that were previously characterized by their different radiosensibility $[4,46]$. Schematic representation of the anionic small molecule $[0-\mathrm{COSAN}]^{-}$ is displayed in Figure 2c.
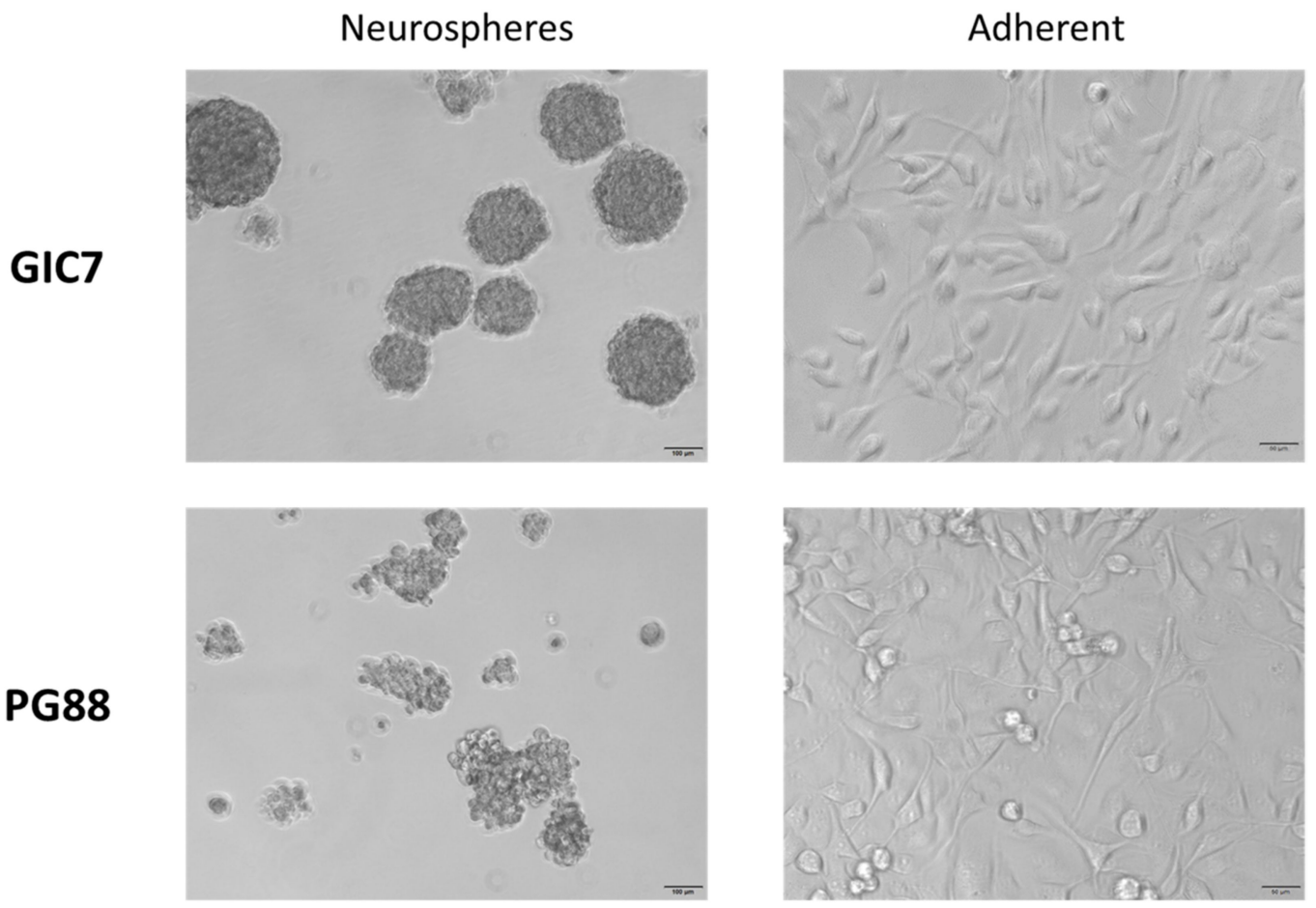

Figure 1. Morphology of glioblastoma initiating cells (GICs). Proneural GIC7 (top) and mesenchymal PG88 (bottom) cells grow performing neurospheres (left, $4 \times$, scale bar $100 \mu \mathrm{m}$ ) or adhered on laminin-coated plates (right, 10×, scale bar 50 $\mu \mathrm{m}$ ) when cultured in a complete Neuronal Stem Cell medium at $37^{\circ} \mathrm{C}$ in a humidified $5 \% \mathrm{CO}_{2}$ and $5 \% \mathrm{O}_{2}$ atmosphere (hypoxia conditions) to simulate the brain microenvironment.

Laminin-coated GICs' exposed at $200 \mu \mathrm{M} \mathrm{Na}[o-C O S A N]$ were analyzed at $282 \mathrm{~nm}$ wavelength using UV-visible spectroscopy. To assess cellular uptake we measured the optical density of adhered cells at different exposition times: $0,15,30,45$, and $60 \mathrm{~min}$. The ratio between the absorbance (Abs) of treated cells to the untreated controls were calculated for each time-point (Figure 2). Abs was recorded at $282 \mathrm{~nm}$ wavelength, which corresponded to the maximum $\lambda$ of $[0-\mathrm{COSAN}]^{-}[44,47,48]$.

$\mathrm{Na}[o-C O S A N]^{-}$has the unusual property of self-assembling into vesicles on biological cell membranes [29]. Thus, $\mathrm{Na}[o-\mathrm{COSAN}]$ levels increased in the intracellular compartment of GIC7 and PG88 cells at $15 \mathrm{~min}$ (Figure 2a). After $30 \mathrm{~min}$, the concentration of [oCOSAN $]^{-}$increased in cellular extracts in both the cell types. These results indicated that $\mathrm{Na}[o-\mathrm{COSAN}]$ can cross the cellular membrane and enter the cells in a short period, suggesting a fast transport from the extracellular compartment. Moreover, $\mathrm{Na}[o-\mathrm{COSAN}]$ uptake was higher in PG88 than in GIC7 cells $(0.17 \mathrm{~nm}$ and $0.03 \mathrm{~nm}$, respectively) at 15 min (two-way ANOVA and Bonferroni posttests, $p<0.05$ ), and differences between both cells were maintained until the end of the experiment one hour later (Figure 2a), when the intracellular levels of the compound decreased in both $(0.047$ and $0.0002 \mathrm{~nm}$, respectively). Altogether, we concluded that a fast $\mathrm{Na}[o-\mathrm{COSAN}]$ internalization occurred in both, mesenchymal and proneural cells, with mesenchymal PG88 cells being the most efficient in capturing the compound. 
a

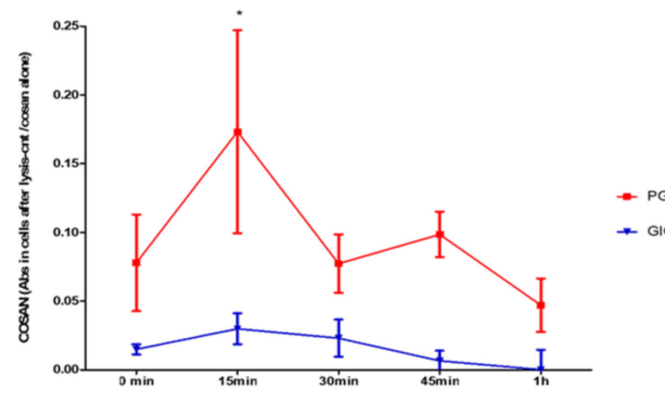

b

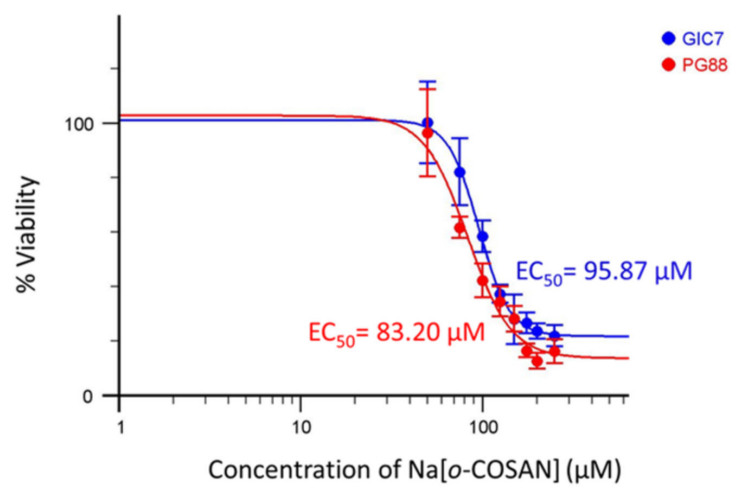

C

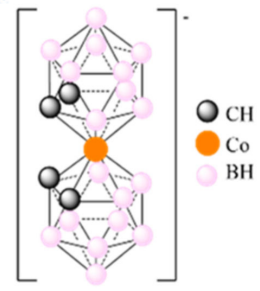

Figure 2. Kinetic of $\mathrm{Na}[\mathrm{o}-\mathrm{COSAN}]$ uptake in glioma undifferentiated cells (GICs). Proneural (GIC7) and mesenchymal (PG88) GICs cultured on laminin-coated wells, 300,000 GICs/well, were seeded $24 \mathrm{~h}$ before treated with $\mathrm{Na}[o-\mathrm{COSAN}](200 \mu \mathrm{M})$. (a) Time course analysis of $\mathrm{Na}[o-\mathrm{COSAN}]$ uptake in lysed cells from GIC7 (blue) and PG88 (red) respective cultures are represented from Spectrometric $\mathrm{Na}[o-\mathrm{COSAN}]$ data analyzed (Synergy), plotted as the percentage of untreated cell cultures, mean $\pm \mathrm{SD}$, of three independent experiments. The uptake of the compound increased at $15 \mathrm{~min}$ of treatment on both GICs, being higher in PG88 concerning GIC7 (ANOVA, ${ }^{*} p<0.05$ ). (b) $\mathrm{Na}$ [o-COSAN] half-maximal effective concentration $\left(\mathrm{EC}_{50}\right)$ at $48 \mathrm{~h}$ in a doses-response curve, ranged 50 to $300 \mu \mathrm{M}$. $\mathrm{EC}_{50}$ of GIC7 $(95.87 \mu \mathrm{M})$ and PG88 $(83.2 \mu \mathrm{M})$ cells are not significantly different. (c) Schematic representation of the anionic small molecule cobaltabis (dicarbollide), $\left[3,3^{\prime}-\mathrm{Co}\left(1,2-\mathrm{C}_{2} \mathrm{~B}_{9} \mathrm{H}_{11}\right)_{2}\right]^{-}$, abbreviated as $[o-\mathrm{COSAN}]^{-}$.

The dynamic profiling of $\mathrm{Na}[o-\mathrm{COSAN}]$ is crucial in BNCT, based on the nuclear capture and fission reactions that occur when the stable ${ }^{10} \mathrm{~B}$ isotope is irradiated with epithermal neutrons $(10,000 \mathrm{eV})$ and become thermalized as they penetrate tissue [16]. The destructive effects of the $\alpha$ particles are limited to the ${ }^{10} \mathrm{~B}$ atoms of the boron-containing cells and, because they have very short path lengths in tissues (5-9 $\mu \mathrm{m})$, BNCT provides a way to selectively destroy malignant cells and spare surrounding normal tissue, making it, in theory, an ideal type of radiation therapy [15].

We analyzed the $\mathrm{Na}[\mathrm{o}-\mathrm{COSAN}]$ half-maximal effective concentration $\left(\mathrm{EC}_{50}\right)$ in a doses-response curve at 50 to $300 \mu \mathrm{M}$ range concentration. $\mathrm{EC}_{50}$ values were calculated using exponential curve fitting. Controls without $\mathrm{Na}$ [o-COSAN] were considered $100 \%$ of viability to evaluate and graphically represent using the https:/ / www.aatbio.com/tools / ec50-calculator program (accessed on 10 March 2020). (Figure 2b).

The viability assay measured at $43 \mathrm{~h}$ after treating the cells for five hours showed that $\mathrm{EC}_{50}$ was lower in PG88, $83.2 \pm 9.652 \mu \mathrm{M}$ (95\% confident intervals: 62.99 to 102.7), than in GIC7 cells, $95.87 \pm 7.592 \mu \mathrm{M}$ (95\% Confidence Intervals: 80.52 to 111.7), suggesting that GIC7 cells were more resistant than PG88 cells when challenged with $[o-\mathrm{COSAN}]^{-}$ (ANOVA $p$-value 0.0023).

Since mesenchymal PG88 cells are more resilient than proneural GIC7 cells to conventional radiotherapy, a lower $\mathrm{EC}_{50} \mathrm{Na}[o-\mathrm{COSAN}]$ together with higher uptake of the 
compound in PG88 cells compared to GIC7 cells suggest a new resource to fight against resistant glioblastoma cells. Moreover, both GICs are more susceptible to $\mathrm{Na}$ [o-COSAN] based therapy than other cancer cells, in which preliminary studies showed that $\mathrm{Na}[0-$ COSAN] $\mathrm{EC}_{50}$ of $3 \mathrm{~T} 3$ fibroblast cells was $99 \pm 5.5 \mu \mathrm{M}$, while the most resistant HeLa cells had a $\mathrm{Na}[o-\mathrm{COSAN}] \mathrm{EC}_{50}$ of $157 \pm 8.6 \mu \mathrm{M}$. Hence, we suggest that $\mathrm{Na}[o-\mathrm{COSAN}]$ might be a new glioblastoma potential therapeutic compound to be used in BNCT.

More experiments are needed to understand the biological reason of these kinetics variations between GIC7 and PG88 glioblastoma cells. It was demonstrated that the major problem with boron compounds is the significant variability in tumor uptake, especially in brain tumors. It has been calculated that, in order to be effective, approximately $20-30 \mu \mathrm{g}$ of ${ }^{10} \mathrm{~B}$ per gram of tumor, which corresponds to $10^{9}$ atoms of ${ }^{10}$ Boron must be selectively delivered to individual cancer cells [17].

The pro-inflammatory environment induced by glioblastoma radiation therapy drives oncogenic signaling that confers radio resistance and activates mechanisms involved in the progression of proneural cells to a more aggressive mesenchymal phenotype with a more likelihood of disease relapse [49]. Therefore, BNCT appears as an attractive alternative to treat recurrent mesenchymal glioblastoma that has developed post-surgical photon irradiation resistance.

$\mathrm{Na}[o-\mathrm{COSAN}]$ elicits a range of cell biological effects, including altered cell morphology, inhibition of cell growth, and, in some cases, apoptosis [45]. We checked morphological changes of both GICs, PG88 and GIC7, by microscopy after $5 \mathrm{~h}$ of treatment of $200 \mu \mathrm{M}$ and $2 \mathrm{mM} \mathrm{Na}[o-\mathrm{COSAN}]$ (Figure 3). The shape of cells turned in less spicular and brightness suggesting that cell death started in both GIC7 (Figure 3a) and PG88 (Figure 3b) cells. This morphology reverted $43 \mathrm{~h}$ after $\mathrm{Na}[0-\mathrm{COSAN}]$ was removed and replaced by fresh complete culture medium as the cells recovered their usual morphological appearance, similar to control cells without the compound. Even when we treated cells with $2 \mathrm{mM} \mathrm{Na}[o-\mathrm{COSAN}]$, which induced intense changes on GIC7 and PG88 cells at $5 \mathrm{~h}$ treatment, the remaining cells recovered their shape $43 \mathrm{~h}$ after washing out the compound (Figure 3a,b), with PG88 cells being the most affected. These results suggested that in both glioblastoma cells, a transient cytostatic effect is induced by $\mathrm{Na}[0-\mathrm{COSAN}]$ instead of cytotoxicity, compatible with compound accumulation within cells, without affecting membrane integrity. Similar results were found previously in HeLa cells that showed an unusual, highly vacuolated morphology within the perinuclear cytoplasm when grown in the presence of $\mathrm{Na}[0-\mathrm{COSAN}]$ [50], that reverted to their native morphology seen in untreated cells, at either 5 and $12 \mathrm{~h}$ after washout $[o-\mathrm{COSAN}]^{-}$. Moreover, Plesek reported that most of the polyhedral boranes are essentially nontoxic due to their inertness to biochemical reactions [51]. Later, some of the authors demonstrated [52] that the protonated and sodium salts of [o-COSAN]- possess the ability to readily cross biological membranes $[52,53]$ even being negatively charged and accumulate inside living cells with no appreciable effect on cell viability. Since [o-COSAN]- is non- cytotoxic [51], but is cytostatic over long term, and cells are recovered following its removal [50], we can state that the results are consistent with others in the literature. 
a

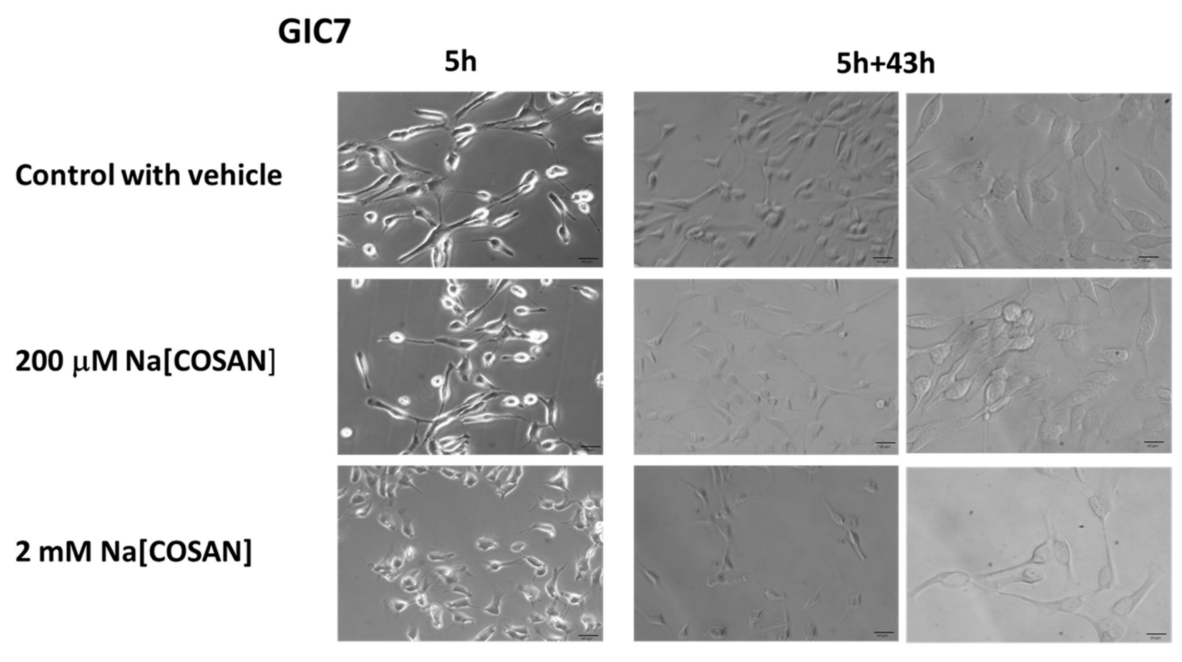

b

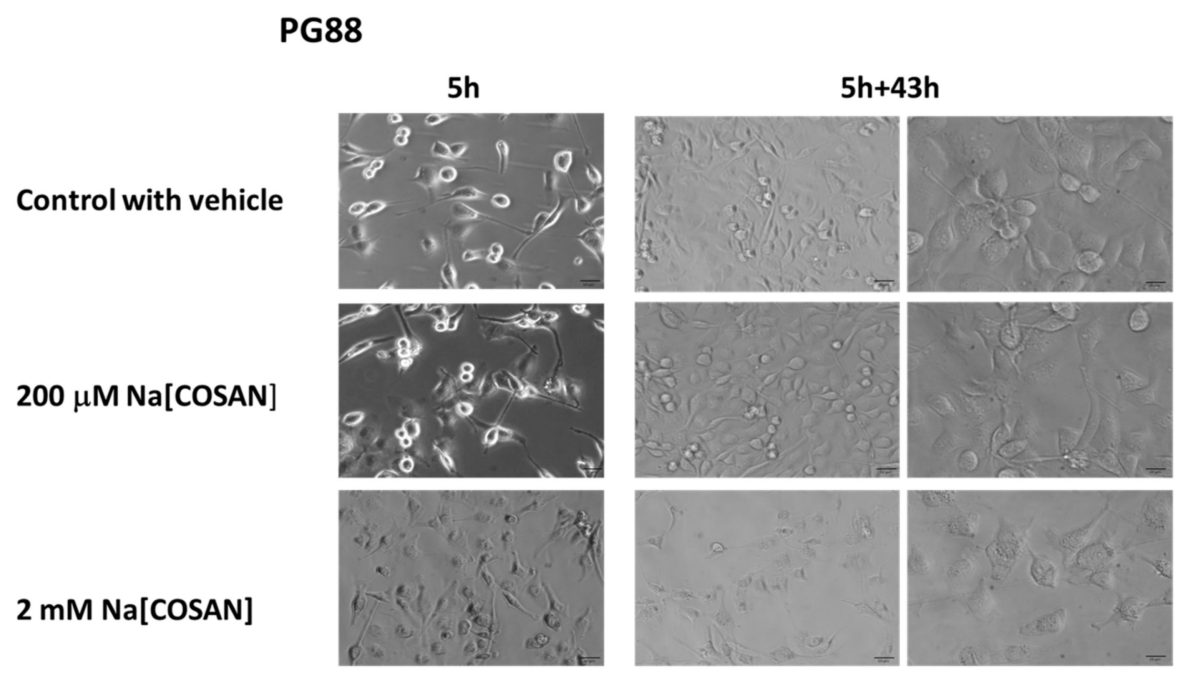

Figure 3. Morphology of glioblastoma initiating cells (GICs) treated with $\mathrm{Na}$ [o-COSAN]. Microscopy comparative analysis at $5 \mathrm{~h}$ treatment with $\mathrm{Na}[o-C O S A N] 200 \mu \mathrm{M}$ and $2 \mathrm{mM}$ (left panels of $(\mathbf{a}, \mathbf{b})$ concerning untreated cells, and $43 \mathrm{~h}$ after washing out $\mathrm{Na}[o-\mathrm{COSAN}](\times 10$ and $\times 20$, middle and right panels magnificence, scale bars $50 \mu \mathrm{m}$ in left and middle and and $25 \mu \mathrm{m}$, in right). Morphological changes on both GICs appear at $2 \mathrm{mM}$. GIC7 looks less affected than PG88 after 2 mM treatment and both cells show similar recovery after washing out the compound.

We analyzed by flow cytometry the cell-cycle process that consists of four distinct ordered phases: $G_{0} / G_{1}$ (gap 1), DNA synthesis, $G_{2}$ (gap 2), and M (mitosis), highly conserved and precisely controlled to govern the genome duplication. GICs treated with $200 \mu \mathrm{M} \mathrm{Na}$ [o-COSAN] $5 \mathrm{~h}$ showed no differences concerning control cells, neither GIC7 nor GP88, (Figure 4a,b, left). When GIC7 cells were morphologically recovered, $43 \mathrm{~h}$ after washing off the compound, we found a decreased $\mathrm{G}_{0} / \mathrm{G}_{1}$ subpopulation (two-way ANOVA and Bonferroni posttests, $p<0.01$ ), about untreated control cells (Figure 4a right) and appeared a sub- $\mathrm{G}_{0}$ population (two way ANOVA and Bonferroni posttests, $p<0.05$ ) compatible with cells dead, whereas the increase in $\mathrm{G}_{2} / \mathrm{M}$ (two way ANOVA and Bonferroni posttests, $p<0.05$ ) subpopulation suggested the recovery of cells engaging a new cell cycle round. Similar results, statistically insignificant, were also found in PG88 cells (Figure $4 \mathrm{~b}$ right). 
a

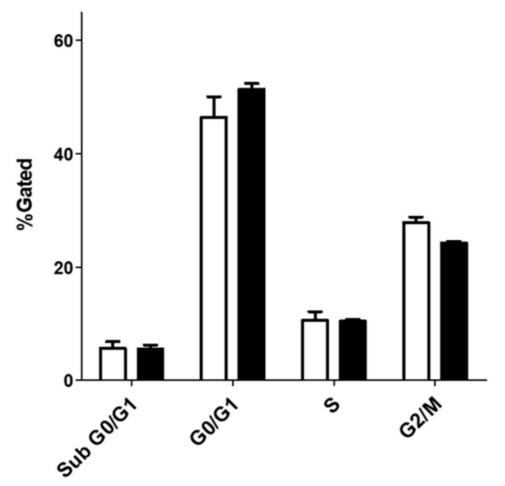

b

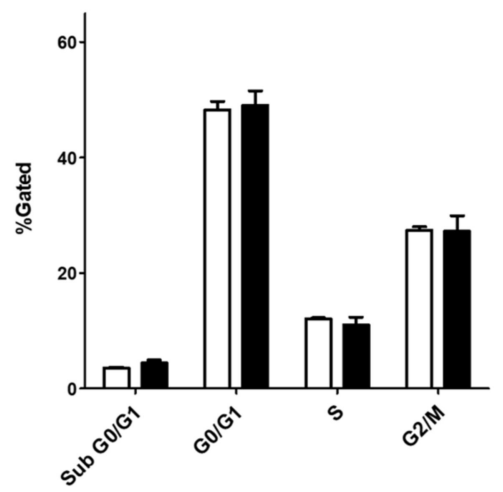

GIC7

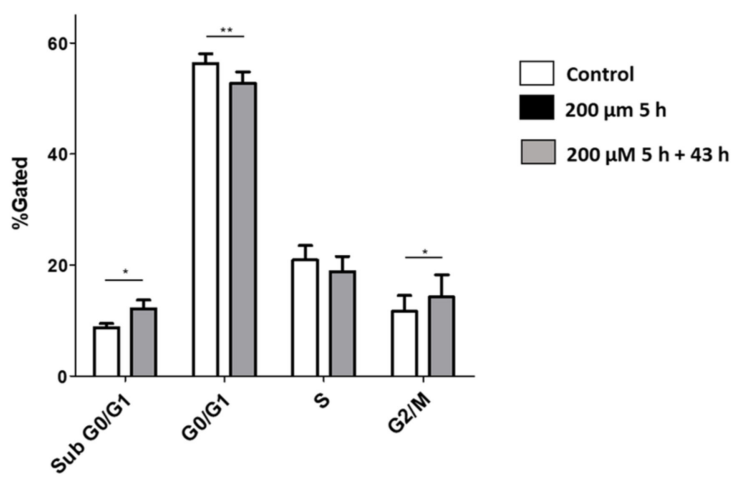

PG88

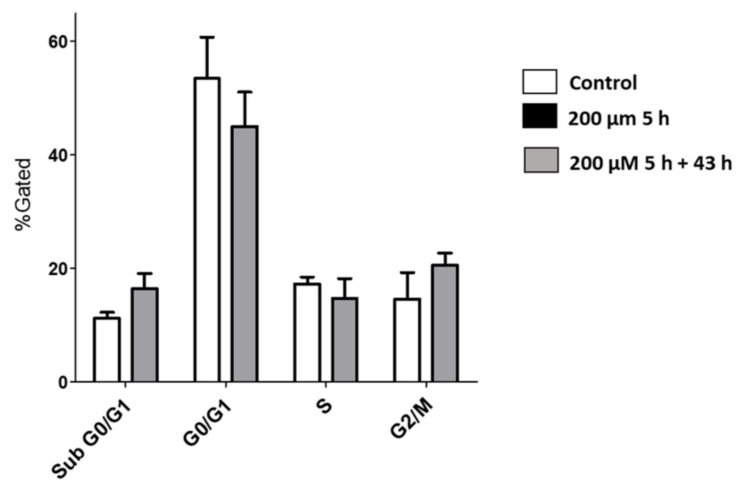

Figure 4. GIC7 and GP88 cell cycle changes induced by $200 \mu \mathrm{M} \mathrm{Na}[o-\mathrm{COSAN}] 5 \mathrm{~h}$ treatment. Scheme 7. (a) nor PG88 (b) concerning their respective untreated controls. (a) GIC7 cell cycle at $43 \mathrm{~h}$ after washing out the $\mathrm{Na}$ [o-COSAN] (right panel) shows changes of sub $\mathrm{G}_{0}, \mathrm{G} 0 / \mathrm{G} 1$ and G2/M statistically significant (ANOVA, ${ }^{*} p<0.05$; ${ }^{* *} p<0.01$, respectively) (b) GP88 cell cycle at $43 \mathrm{~h}$ after wash out the $\mathrm{Na}[o-\mathrm{COSAN}]$ (right panel) shows some differences in G0/1, G2/M and S phase not statistically significant.

Since the $G_{1}$ and $G_{2}$ phases are critical regulatory checkpoints [54], whereby the restriction point between the $G_{1}$ and $S$ phase determines whether the cells enter the $S$ phase or exit the cell cycle, cells recovering from $\mathrm{Na}[o-\mathrm{COSAN}]$ effect are halted at the $\mathrm{G}_{0}$ phase and a small percentage died. When cells are recovered, $43 \mathrm{~h}$ after treatment, they might enter in $\mathrm{G}_{2} / \mathrm{M}$ phase to complete division. Consequently, these results indicated that $\mathrm{Na}[o-\mathrm{COSAN}]$ has a cytostatic effect on both GIC7 and PB88 cells with an increased recovery of GIC7 over PG88, suggested by the differences between them on $G_{2} / M$, and probably due to the higher $\mathrm{EC}_{50}$ of GIC7 cells.

\subsection{GICs Na[o-COSAN] Uptake Analysis by SR-FTIRM and Multivariate Analysis}

Synchrotron-based Fourier-transform infrared micro-spectroscopy (SR-FTIRM), which is a non-destructive methodology with minimal sample's preparation and no requirement of radioactive labeling, facilitates the acquisition of biochemical signatures from cellular material (DNA, proteins, and lipids) based on the intrinsic molecular vibrations of the chemical bonds present [55]. SR-FTIRM is one of the fastest tools to get important information about the chemical compounds in the molecular and sub-molecular structure of living cells. It provides the possibility to perform a qualitative and quantitative analysis at the molecular level. Biological samples include a mixture of proteins, nucleic acids, lipids, and carbohydrates; all these biochemical contents have specific absorption bands in the infrared frequency domain. In SR-FTIRM, the radiation is absorbed by the sample 
at specific frequencies corresponding to their chemical bond inherent vibrational mode. A change in the chemical environment of a bond can result in peak shifts and/or bands intensity change. A single base discrimination difference in oligonucleotides sequences of DNA has been previously distinguished [56]. As SR-FTIR spectroscopy typically gives rise to hundreds of wavenumbers per spectral acquisition, multivariate analysis is required because of the large volume of data acquired. Such multivariate analysis can be performed with principal component analysis (PCA), which facilitates unsupervised data reduction on the processed spectra [56]. Scores' plots provide a visual interpretation of the spread of data and cluster vector plots allow identification of the wavenumbers responsible for segregation and any similarities or differences between classes.

The potential of using spectroscopic techniques for the analysis of DNA extracted from cells or tissues could enable new insights into diseases related to epigenetic events. The main objective of this study was to investigate by SR-FTIR micro-spectroscopy the interaction of $[0-\mathrm{COSAN}]^{-}$anion with the different groups of cell's biomolecules (lipids, proteins, and DNA) after the [o-COSAN $]^{-}$uptake by two GICs, PG88 and GIC7. Subsequently, we analyzed:

(i) IR spectra of $\mathrm{Na}[o-\mathrm{COSAN}]$ at GICs.

The first step of this study was to acquire the IR spectrum of $\mathrm{Na}$ [o-COSAN] in solidstate and in $2 \mathrm{mM}$ solution of water and NSC medium to analyze the influence of both components, $\mathrm{H}_{2} \mathrm{O}$ and NSC medium, on the $\mathrm{Na}[o-\mathrm{COSAN}]$ IR spectrum (Figure 5) and take them as reference for the GICs SR-FTIR spectroscopy. To emphasize that all three $\mathrm{Na}[o-\mathrm{COSAN}]$ spectra display a strong and characteristic $v(\mathrm{~B}-\mathrm{H})$ frequency in the infrared range $2.600-2.500 \mathrm{~cm}^{-1}$ in which no other frequencies of organic compounds appear. The IR spectrum of $\mathrm{Na}[o-\mathrm{COSAN}]$ in solid-state (Figure $5 \mathrm{a}$, grey) displays the $v(\mathrm{~B}-\mathrm{H})$ and $v\left(\mathrm{C}_{\mathrm{c}}-\mathrm{H}\right)$ frequencies at 2582-2522 and $3031 \mathrm{~cm}^{-1}$, respectively. Bands at 3590, 3561, and $3518 \mathrm{~cm}^{-1}$ correspond to $\mathrm{H}_{2} \mathrm{O}$ coordinated to the Na cation. The IR spectrum of $2 \mathrm{mM}$ aqueous solution of $\mathrm{Na}$ [o-COSAN] (Figure $5 \mathrm{a}$, orange) is similar to the one in solid-state, but non-coordinated water from the solvent is also observed, while the IR spectrum of $2 \mathrm{mM}$ solution of $\mathrm{Na}[o-\mathrm{COSAN}]$ in the culture media (Figure 5a, blue) is different. In the latest spectrum, the frequencies related to the $\mathrm{H}_{2} \mathrm{O}$ and $v\left(\mathrm{C}_{\mathrm{c}}-\mathrm{H}\right)$ are not observed by visual examination and the peak intensity of the signal related to the $v(\mathrm{~B}-\mathrm{H})$ decreases; it is a clear indication of an alteration in the chemical environment of the $\mathrm{B}-\mathrm{H}$ and $\mathrm{C}_{\mathrm{c}}-\mathrm{H}$ bonds, which can be related to the interaction between $\mathrm{Na}[o-\mathrm{COSAN}]$ and the nutrient biomolecules (proteins and amino acids) present in the NSC culture media.

(ii) $\mathrm{Na}[\mathrm{o}-\mathrm{COSAN}]$ uptake and localization on GICs.

To analyze the changes induced by the uptake of $\mathrm{Na}[o-\mathrm{COSAN}]$ into the GIC cells, each cells line was incubated in a complete culture medium containing $200 \mu \mathrm{M}$ or $2 \mathrm{mM}$ of $\mathrm{Na}[o-\mathrm{COSAN}]$ for $5 \mathrm{~h}$. Further, the two cell lines were studied using SR-FTIR microspectroscopy. Three different samples per cell line were analyzed, recording the spectra of $100-200$ cells in each sample. The experiments were performed as described in the methods section. Once the spectra were recorded, they were statistically analyzed separately at the lipids region and fingerprint region, which includes mainly proteins and DNA, by using PCA.

Well-defined peaks in the SR-FTIR averaged spectra were observed in treated GICs with $\mathrm{Na}[o-\mathrm{COSAN}]$, either GIC7 or GP88, compared with the corresponding cell's control (Figure $5 \mathrm{~b}$ ). The B-H stretching signal from the $\mathrm{Na}[o-C O S A N]$ appears at $2557 \mathrm{~cm}^{-1}$ with a sub-peak at $2537 \mathrm{~cm}^{-1}$. The intensity of the IR peak is proportional to the amount of compound. As seen in Figure 5b, the peak from B-H signal observed in GIC7 cells after $200 \mu \mathrm{M} \mathrm{Na}$ [o-COSAN], 5 hours' treatment, was small but detectable (Figure $5 \mathrm{~b}, \mathrm{c}$, orange), but increased in both cell lines at $2 \mathrm{mM} \mathrm{Na}[o-\operatorname{COSAN}]$ (Figure $5 \mathrm{~b}, \mathrm{c}$, light blue). 

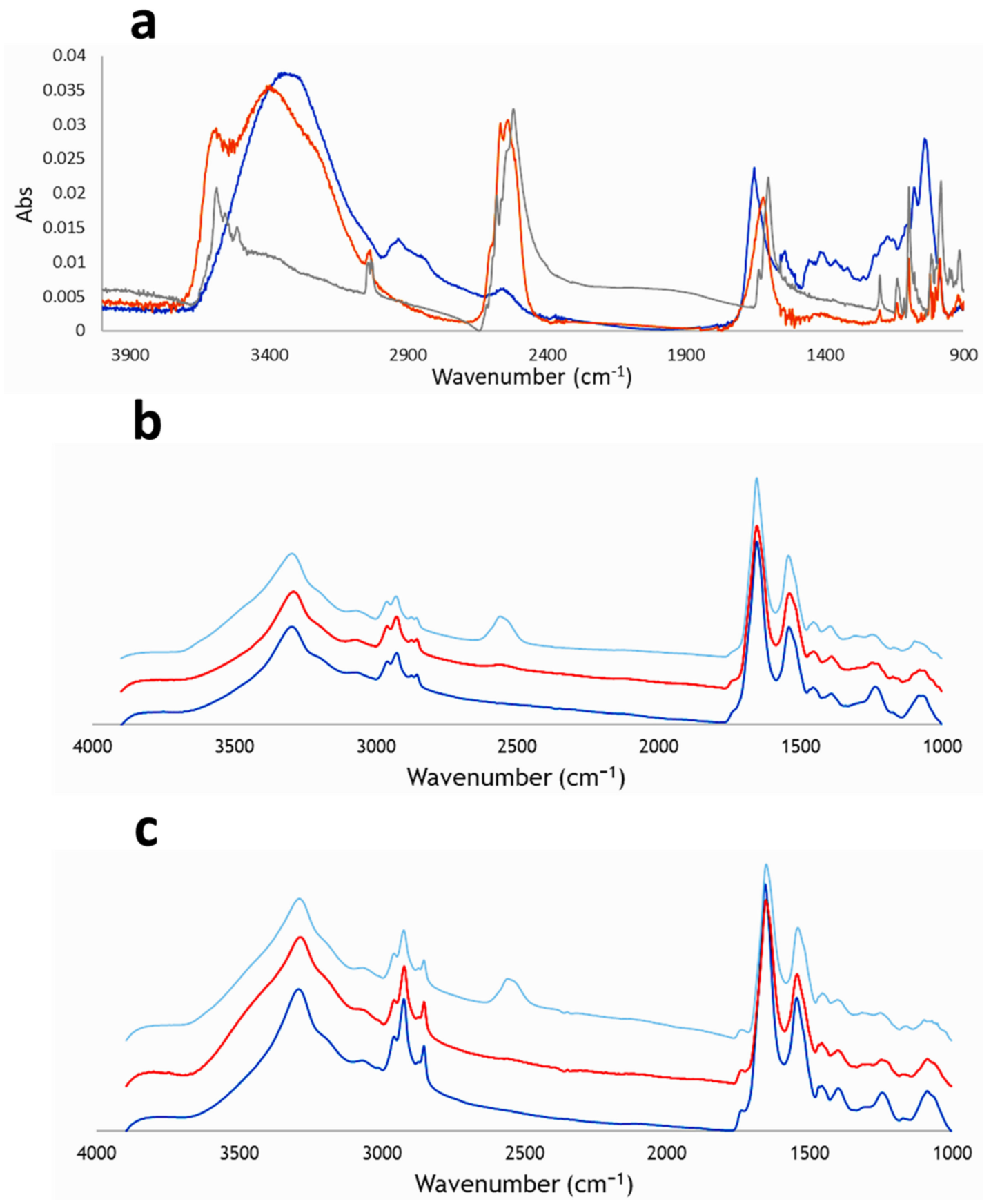

Figure 5. GICs $\mathrm{Na}[o-\mathrm{COSAN}]^{-}$uptake analyses by SR-FTIRM. $\mathrm{Na}[o-\mathrm{COSAN}]$ spectra display a strong and characteristic $v(\mathrm{~B}-\mathrm{H})$ frequency at the infrared range $2.600-2.500 \mathrm{~cm}^{-1}$ in which no other frequencies of organic compounds appear. The IR spectrum of $\mathrm{Na}[o-\mathrm{COSAN}]$ in solid-state displays the $v(\mathrm{~B}-\mathrm{H})$ and $v\left(\mathrm{C}_{\mathrm{c}}-\mathrm{H}\right)$ frequencies at $2582-2522$ and at $3031 \mathrm{~cm}^{-1}$, respectively. (a) IR spectra of $\mathrm{Na}[o-\mathrm{COSAN}]$ recorded in solid-state (grey), $2 \mathrm{mM}$ of $\mathrm{Na}[o-\mathrm{COSAN}]$ in aqueous solution (orange) and $2 \mathrm{mM}$ of $\mathrm{Na}[o-\mathrm{COSAN}]$ in culture media solution (blue). (b) IR spectra of GIC7 cells: control cells (dark blue), cells incubated with $200 \mu \mathrm{M}$ of $\mathrm{Na}[o-C O S A N]$ for $5 \mathrm{~h}$ (red) and, cells incubated with $2 \mathrm{mM}$ of $\mathrm{Na}[o-\mathrm{COSAN}]$ for $5 \mathrm{~h}$ (light blue). (c) IR spectra of PB88 cells: control cells (dark blue), cells incubated with $200 \mu \mathrm{M}$ of Na[o-COSAN] for $5 \mathrm{~h}$ (red) and, cells incubated with $2 \mathrm{mM}$ of $\mathrm{Na}$ [o-COSAN] for $5 \mathrm{~h}$ (light blue).

(iii) Study of the SR-FTIR spectra of GICs treated with Na[o-COSAN] $5 \mathrm{~h}$.

The IR spectra were measured in the wavenumber range $4000-800 \mathrm{~cm}^{-1}$. We have studied separately the range region of the different cell components (DNA, proteins, and lipids) in the IR spectrum, which corresponds to $1350-900,1800-1480$, and $3000-2800 \mathrm{~cm}^{-1}$, respectively. 
Nucleic acids and sugars appear in the region $1350-900 \mathrm{~cm}^{-1}$ in which the symmetric and antisymmetric vibrations of the phosphodioxy $\left[(\mathrm{RO})_{2} \mathrm{PO}_{2}\right]^{-}$groups appear [57]. The range $1800-1480 \mathrm{~cm}^{-1}$ corresponds to amide I vibrations (due to $\mathrm{C}=\mathrm{O}$ and C-N stretching bands) and amide II vibrations (due to $\mathrm{N}-\mathrm{H}$ bending and $\mathrm{C}-\mathrm{N}$ stretching bands). The mean cellular contributors in the range $3000-2800 \mathrm{~cm}^{-1}$ correspond to fatty acids and lipids because of the alkyl chain stretching vibrations while the deformation vibrations of their $\mathrm{CH}_{2}$ and $\mathrm{CH}_{3}$ alkyl groups appear in the area $1480-1300 \mathrm{~cm}^{-1}$ [58].

We performed microscopy images of GIC7 cells treated with $\mathrm{Na}[o-\mathrm{COSAN}] 2 \mathrm{mM}$ and, $5 \mathrm{~h}$ to assess the intracellular location of the compound. Mappings were acquired by integrating the $v(\mathrm{~B}-\mathrm{H})$ signals between 2620 and $2460 \mathrm{~cm}^{-1}$ spectra in different areas of the culture. The analysis showed cell maps in which the color intensity was proportional to $\mathrm{Na}[o-C O S A N]$ concentration (Figure 6). This mapping suggested the nuclear localization of the compound. These experimental results agree with the reported theoretical study, which found that hydrophobicity and the negative charge of nanoparticles are necessary for their translocation through the nuclear pore [59].

a

b
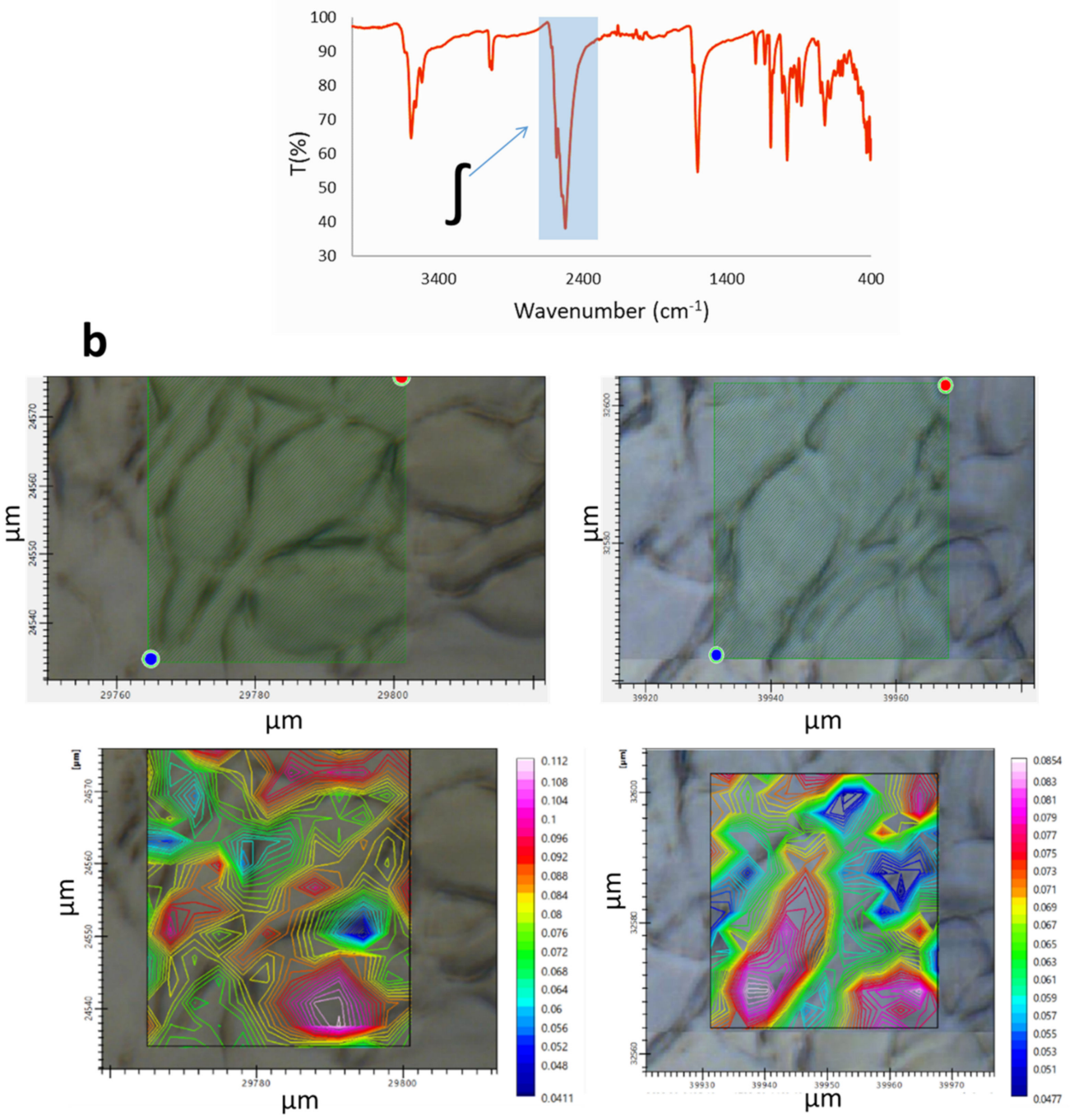

Figure 6. Microscopy images of GIC7 cells treated with Na[o-COSAN] $2 \mathrm{mM}, 5 \mathrm{~h}$ and mappings were obtained by integrating the $v(\mathrm{~B}-\mathrm{H})$ signals between 2620 and $2460 \mathrm{~cm}^{-1}$ spectra (a). Two different areas of culture cells are shown with the corresponding maps (b). The red color intensity is proportional to $\mathrm{Na}[\mathrm{o}-\mathrm{COSAN}]$ spectra suggesting the nuclear localization of the compound. 
Moreover, Monte Carlo simulations showed that the amount of boron for BNCT should be localized preferably within or near the nucleus because the energy deposition in the nucleus of cells exposed to the neutron reaction results in a more efficient cell-killing effect compared to that in a uniform distribution within the entire cell [60].

In summary, cell mapping was acquired to determine the uptake of $\mathrm{Na}$ [o-COSAN], and spectroscopic data were obtained from bands in the regions that corresponded to the DNA, proteins, and lipids, which suggest that $\mathrm{Na}[o-\mathrm{COSAN}]$ interacts with DNA strands, modify proteins structure, and lipids saturation, inducing changes in the lipid-protein ratio. These data suggest that $\mathrm{Na}[0-\mathrm{COSAN}]$ is a real and new promising anionic inorganic small molecule candidate that might be used in BNCT of glioblastoma cells.

\subsubsection{SR-FTIRM at the DNA Region}

To analyze the influence of $\mathrm{Na}[0-\mathrm{COSAN}]$ on DNA components of the two GIC cell lines, the PCA of the SR-FTIRM spectra was performed using the $1350-900 \mathrm{~cm}^{-1}$ region spectra second derivative (Supplementary Figure S1a,b). Several differences were observed between GIC7 control and GIC7 treated with $200 \mu \mathrm{M} \mathrm{Na}[o-C O S A N]$ (Figure 7a). Among others, the treatment decreased the intensity and the shape of the phosphate peak at $1250 \mathrm{~cm}^{-1}$ with regard control cells. Similar changes were also observed in PG88 cells (Figure 7b) and in both GICs treated with $2 \mathrm{mM} \mathrm{Na}[o-C O S A N]$ (Supplementary Figure S2a,b).
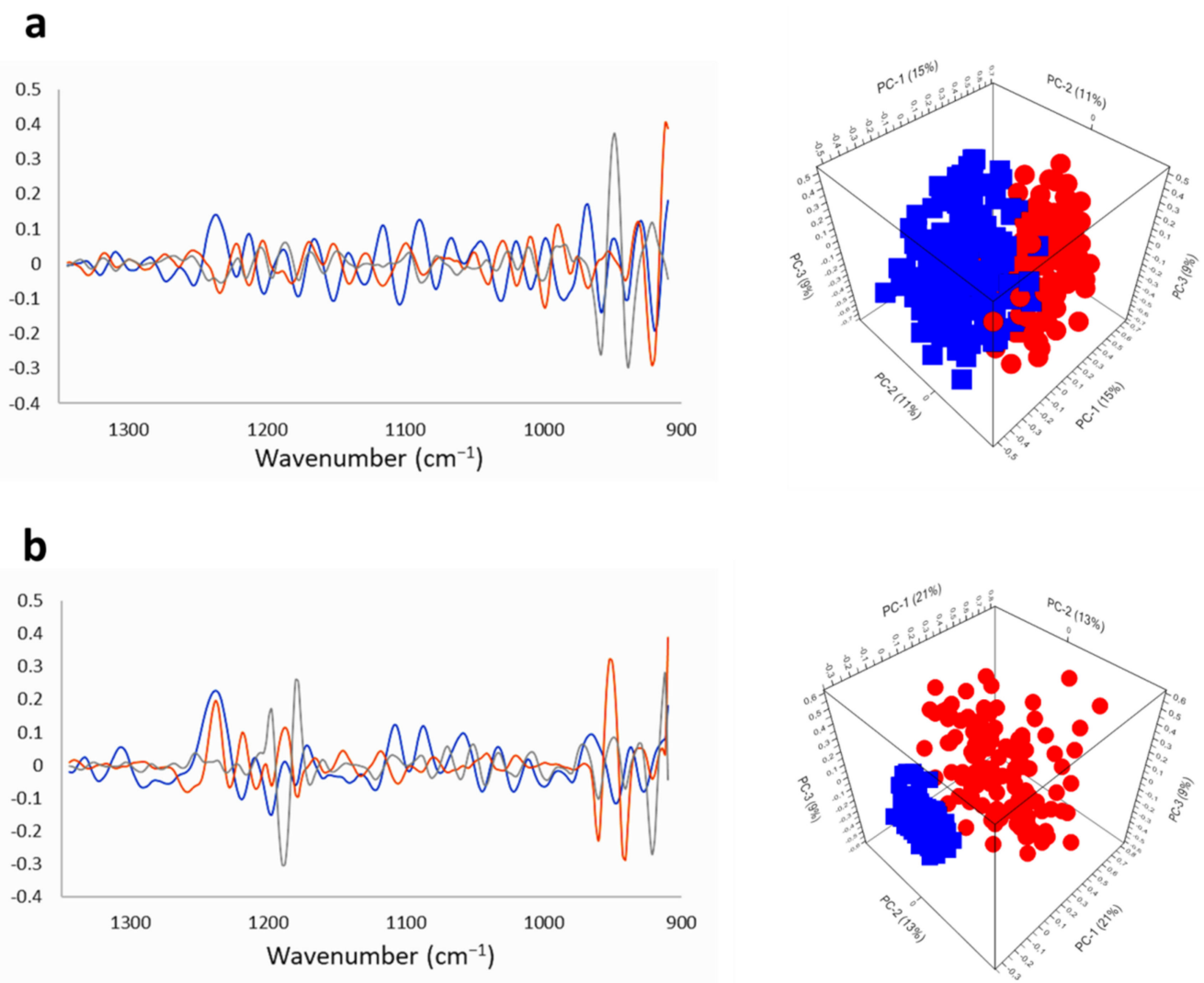

Figure 7. PCA and loadings within the DNA region (1350-900 cm-1) of GICs samples treated with Na[o-COSAN] $200 \mu \mathrm{M}$, 5 h: (a) GIC7 and (b) PG88 cells. Principal component loadings (blue PC-1, orange PC-2, grey PC-3) are shown on left panels. Right-panels principal component analysis score plots of PC-1, PC-2 and PC-3 displaying the variance between GIC control cells (blue) and GIC treated cells (red).

$\mathrm{Na}$ [o-COSAN] induced spectral changes at the DNA region in both GIC cell lines, which are interestingly similar to the changes induced by other metal-based compounds like cisplatin that disrupt the double helix base pairing [61]. These results with $\mathrm{Na}[o-\mathrm{COSAN}]$ go in parallel with previously reported studies that indicated metallabis (dicarbollide)'s strong interactions with DNA; the interaction is intercalative (in between both chains) 
in the case of $\mathrm{Na}$ [o-FESAN] [62] but electrostatic with $\mathrm{Na}$ [o-COSAN] [45]. In addition, previous SR-FTIRM studies on several human cancer cell lines unveiled specific spectral biomarkers of the drug interplay with the DNA (e.g., $v(\mathrm{OPO})$ and $\delta\left(\mathrm{NH}_{2}\right)$ ) both through direct coordination to the double helix and via interference with the surrounding water molecules [63]. Variations were evidenced in DNA's typical features, particularly those assigned to the phosphate groups. Therefore, these results suggest that the therapeutic action of $[o-\mathrm{COSAN}]^{-}$might be based on interacting with DNA molecules of the GICs cells.

\subsubsection{SR-FTIRM at the Region of the Protein}

The absorptions in the spectral range $1800-1350 \mathrm{~cm}^{-1}$ are due to the amide I and amide II vibrations of the proteins (Figures 8 and 9 and S3-S5). To explore the general variation induced by the compound, rubber band baseline correction and vector normalization was applied to raw spectra from the corresponding PCA of this fingerprint region, corrected by extended multiplicative signal correction (EMSC) of control untreated GICs vs. treated GICs with $\mathrm{Na}[o-\mathrm{COSAN}] 200 \mu \mathrm{M}$ for $5 \mathrm{~h}$. Changes of protein profile were observed at 1522 $\mathrm{cm}^{-1}$ and $1641 \mathrm{~cm}^{-1}$ regions. Component PC-2 and PC-3 from PCA analyses of both GICs, GIC7 (Figure 8a) and PG88 (Figure 9a), are different between treated and non-treated cells. Changes in peak shape, absorbance, and peak position of Amides I $1650 \mathrm{~cm}^{-1}$ and 1550 $\mathrm{cm}^{-1}$ were observed. Moreover, at PC-2 the $1666 \mathrm{~cm}^{-1}$ peak Amide I increased on treated PG88 concerning the untreated control cells. In addition, PC-3 included strong changes in Amide I, $1650 \mathrm{~cm}^{-1}$, and DNA, 1250 and $1050 \mathrm{~cm}^{-1}$ peaks.
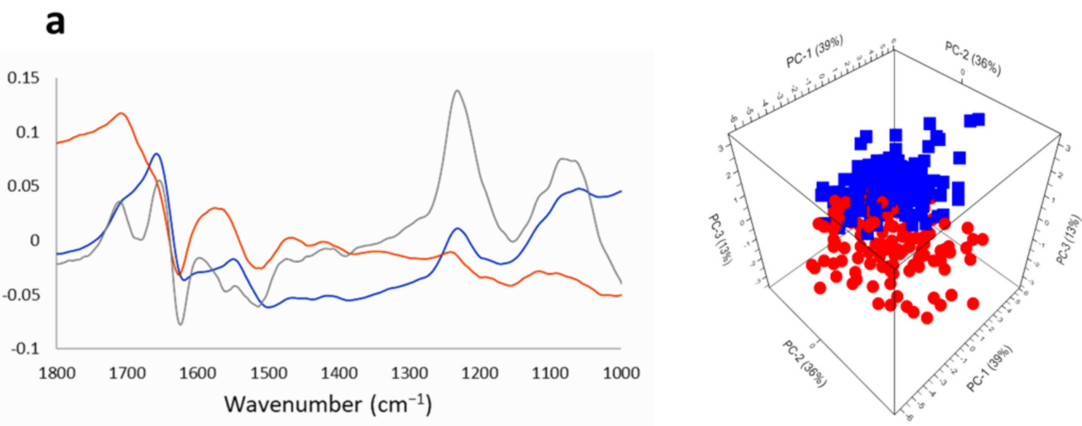

b
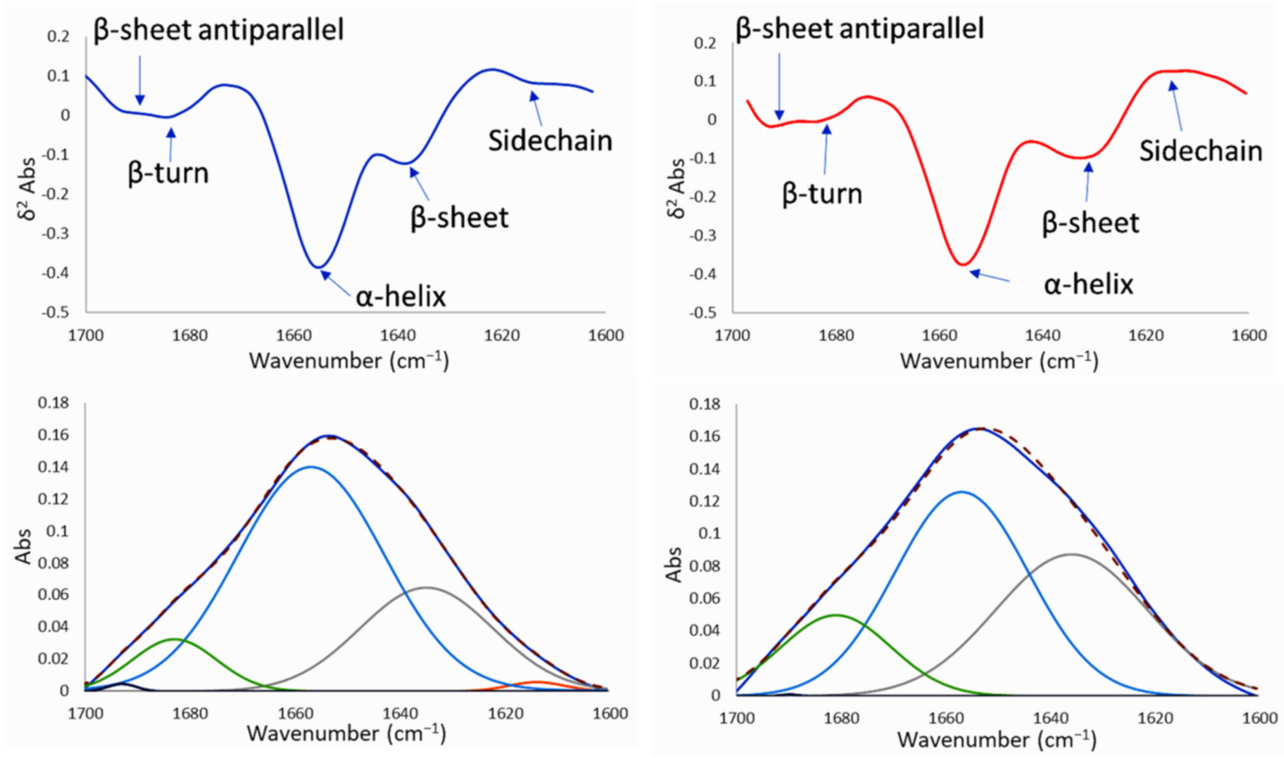

Figure 8. PCA and loadings within the protein region $\left(1800-1000 \mathrm{~cm}^{-1}\right)$ of GIC7 cells treated with $\mathrm{Na}[o-\mathrm{COSAN}] 200 \mu \mathrm{M}, 5 \mathrm{~h}$ : (a) Principal component loadings (blue PC-1, orange PC-2, grey PC-3) and principal components analysis scores plot of PC-1, PC-2 and PC-3 displaying the variance between GIC7 control (blue) and GIC7 treated cells (red). (b) The second derivative of 
FTIR spectrum at Amide I region 1700-1600 $\mathrm{cm}^{-1}$ and its deconvolution is shown to visualize differences between GIC7 untreated control (left) and GIC7 treated cells (right). The deconvolutions follow the following code: Amide I-experimental in dark blue, Sidechain in orange, $\beta$-sheet in grey, $\alpha$-helix in blue, $\beta$-turn in green, $\beta$-sheet antiparallel in black, and Amide I-calculated in red dotted.
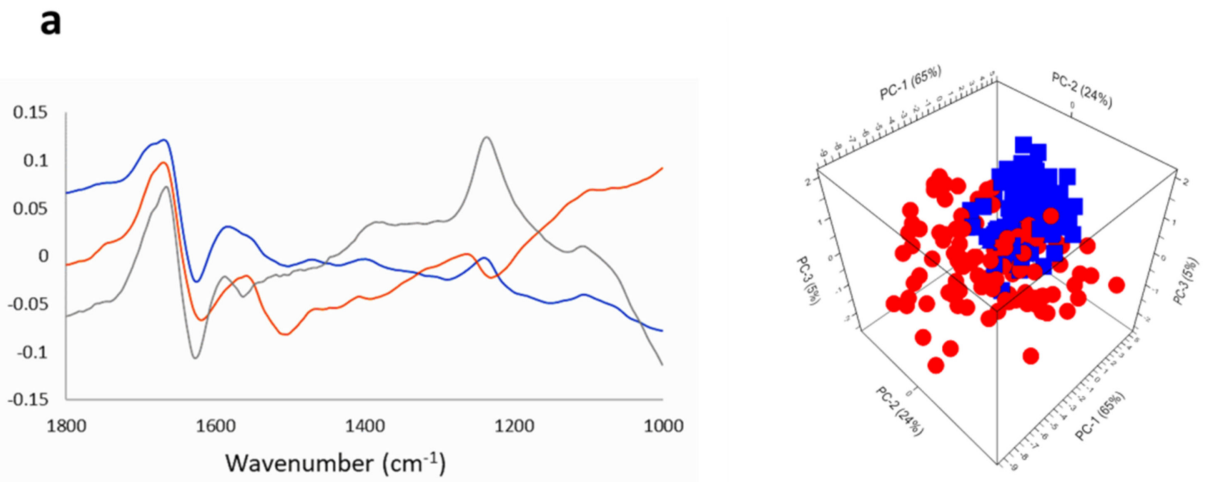

b
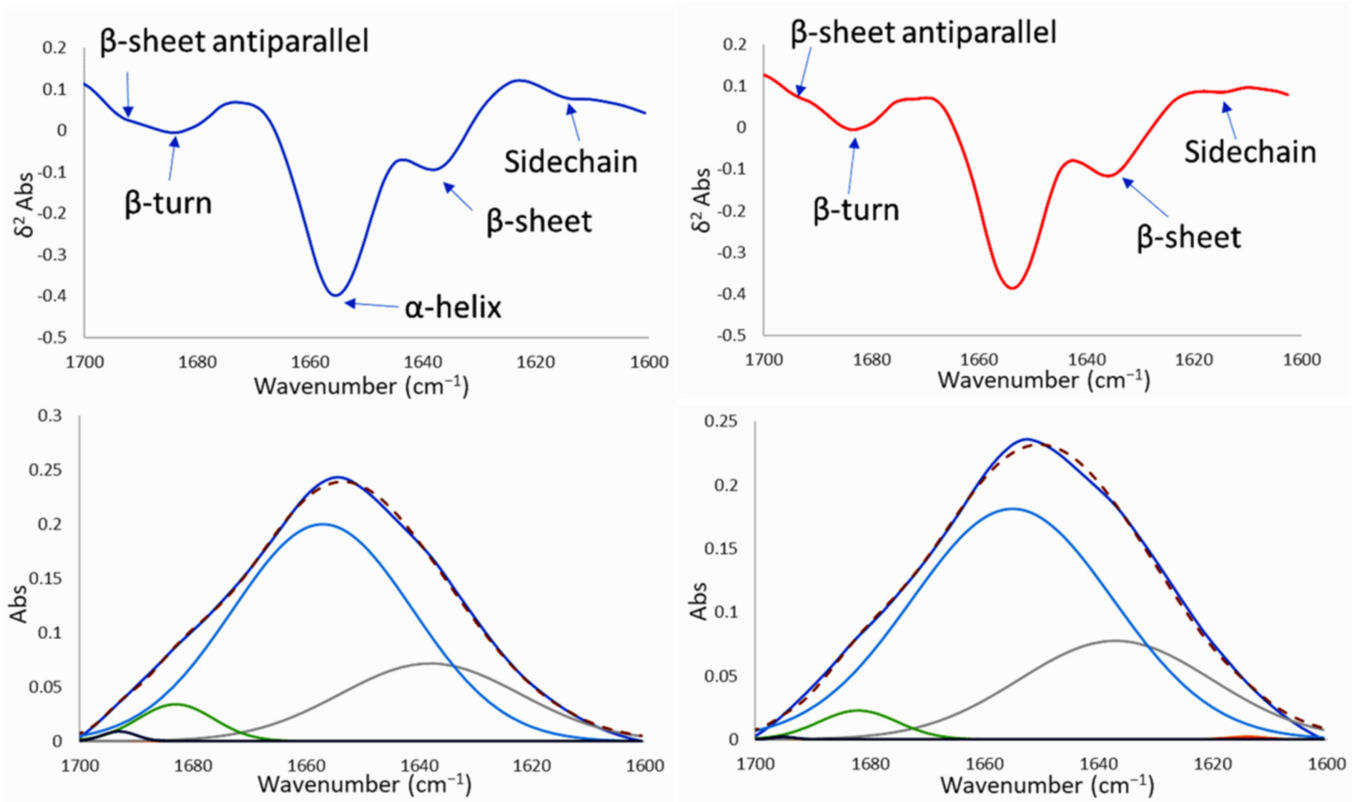

Figure 9. PCA and loadings within the protein region (1800-1000 $\mathrm{cm}^{-1}$ ) of PG88 cells treated with Na[o-COSAN] $200 \mu \mathrm{M}$, 5 h: (a) Principal component loadings (blue PC-1, orange PC-2, grey PC-3) and principal components analysis scores plot of PC-1, PC-2 and PC-3 displaying the variance between PG88 control (blue) and PG88 treated cells (red). (b) The second derivative of FTIR spectrum at Amide I region 1700-1600 cm $\mathrm{cm}^{-1}$ and its deconvolution is shown to visualize differences between PG88 untreated control (left) and PG88 treated cells (right). The deconvolutions follow the following code: Amide I-experimental in dark blue, Sidechain in orange, $\beta$-sheet in grey, $\alpha$-helix in blue, $\beta$-turn in green, $\beta$-sheet antiparallel in black, and Amide I-calculated in red dotted.

The amide I signals were deconvoluted [64] to determine how $\mathrm{Na}$ [o-COSAN] affects the secondary structure of proteins (Figures $8 b$ and $9 b$ ) in both GIC cell lines, GIC7 and PB88. The peaks for the deconvolution were assigned using the 2nd derivative spectrum (Figures $8 \mathrm{~b}$ and $9 \mathrm{~b}$ ), where five bands were assigned to $\beta$-sheet antiparallel (at $1693 \mathrm{~cm}^{-1}$ ), $\beta$-turn (at $1683 \mathrm{~cm}^{-1}$ ), $\alpha$-helix (at $1654 \mathrm{~cm}^{-1}$ ), $\beta$-sheet (at $1637 \mathrm{~cm}^{-1}$ ) and sidechain (at $1614 \mathrm{~cm}^{-1}$ ). The percentage area of $\alpha$-helix and $\beta$-sheet structure of both GICs, control and treated cells, either $5 \mathrm{~h}$ with $200 \mu \mathrm{M}$ (Figures 8 and 9) or with $2 \mathrm{mM}$ of $\mathrm{Na}[o-\mathrm{COSAN}]$ (Supplementary Figure S4), were calculated employing the multipeak curve fitting of the amide I region of the samples. We found a higher proportion of $\alpha$-helix secondary structure in both GICs cell lines, GIC7 and PB88, induced by $\mathrm{Na}[0-\mathrm{COSAN}]$, which inversely increased 
at high concentration of the compound (Table 1). Hen, $\mathrm{Na}[o-\mathrm{COSAN}]$ might interact with proteins, especially with those having a high content of electrically positively charged side-chains, namely arginine, histidine, and lysine amino acids [65]. Therefore, the ratio amide I/amide II decreases with respect to the control cells in both GICs (Supplementary Table S1) [66]. Moreover, the secondary structure of amide I also changed by the treatment because the ratio $\alpha$-helix/ $\beta$-sheet decreased concerning their respective control cells.

Table 1. Ratio of the $\alpha$-helix and $\beta$-sheet Integrated spectra obtained from the deconvolution of Amide I from GICs.

\begin{tabular}{ccc}
\hline Sample & Ratio $\int \alpha / \int \beta$ & $\Sigma$ Error $^{2}$ \\
\hline GIC7 Control & 2.37 & $4.9 \times 10^{-5}$ \\
GIC7 200 $\mu \mathrm{M}$ & 1.26 & $3.8 \times 10^{-4}$ \\
GIC7 2 mM & 2.54 & $2.2 \times 10^{-4}$ \\
\hline PG88 Control & 10.62 & $3.3 \times 10^{-4}$ \\
PG88 200 $\mu \mathrm{M}$ & 7.19 & $7.4 \times 10^{-4}$ \\
PG88 2 mM & 8.00 & $6.6 \times 10^{-4}$ \\
\hline
\end{tabular}

By SR-FTIRM, it has been observed that $\mathrm{Na}[o-\mathrm{COSAN}]$ interacts with proteins, inducing protein conformational changes in GICs. These data are consistent with its reported structure in complex with HIV PR that was determined at $2.15 \AA$ resolution by protein crystallography, and it shows that two molecules of the [o-COSAN $]^{-}$bind to the hydrophobic pockets of HIV protease acting as a potent inhibitor of HIV protease [67].

\subsubsection{SR-FTIRM at the Lipids Region}

The absorptions in the spectral range $3000-2800 \mathrm{~cm}^{-1}$ are from lipids vibrations (Figure 10a,b and S6) [58]. Figure 10 displays the PCA corresponding to this region for GIC7 (Figure 10a) and PB88 cells (Figure 10b), both were performed from raw spectra corrected by EMSC of the GICs control vs. GICs treated with $200 \mu \mathrm{M}$ of $\mathrm{Na}[0$-COSAN] for $5 \mathrm{~h}$. Significant differences were observed in PC-3, where the peaks at $2920 \mathrm{~cm}^{-1}$ and $2850 \mathrm{~cm}^{-1}$ from $-\mathrm{CH}_{2}$ - asymmetric stretching and - $\mathrm{CH}_{2}$ - symmetric stretching were slightly more intense in treated GIC7 with regard untreated control cells (Figure 10a). Furthermore, the frequency of the $\mathrm{C}_{\text {cluster- }} \mathrm{H}$ vibration at $3030 \mathrm{~cm}^{-1}$ showed a slight interaction with proteins or DNA. The ratios between $2960 \mathrm{~cm}^{-1}\left(-\mathrm{CH}_{3}\right.$ asymmetric stretching $)$ and $2921 \mathrm{~cm}^{-1}\left(-\mathrm{CH}_{2}\right.$ - asymmetric stretching) peaks were calculated (Supplementary Table S2) and in treated GIC7 increased concerning GIC7 control. In contrast, the absorbance ratios among the $2960 \mathrm{~cm}^{-1}\left(-\mathrm{CH}_{3}\right.$ asymmetric stretching) and $2921 \mathrm{~cm}^{-1}\left(-\mathrm{CH}_{2}\right.$ - asymmetric stretching) of treated PG88 cells decreased noticeably concerning untreated control cells (Supplementary Table S2).

Finally, the lipids unsaturation index was calculated for both GICs by dividing the integral of the $3010 \mathrm{~cm}^{-1}$ signal (-HC=CH- stretching) by the integral of $2850 \mathrm{~cm}^{-1}$ signal (- $\mathrm{CH}_{2}$ - symmetric stretching) (Supplementary Table S3) [43]. A partial reduction of lipid double bonds was observed in treated GIC7 concerning control cells, which is inversely proportional to $\mathrm{Na}[o-\mathrm{COSAN}]$ concentration, while the unsaturation index of PG88 cells was also slightly affected by the treatment. More studies are needed to understand the lipid changes induced by $\mathrm{Na}[o-\mathrm{COSAN}]$ in GICs and analyze in detail the consequences on specific cellular functions. 

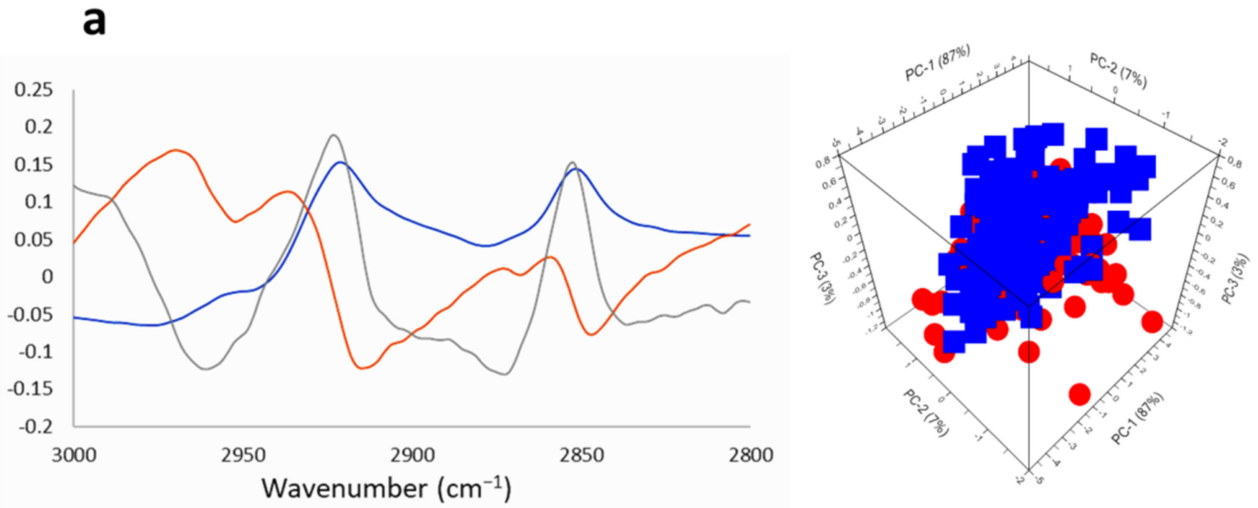

b
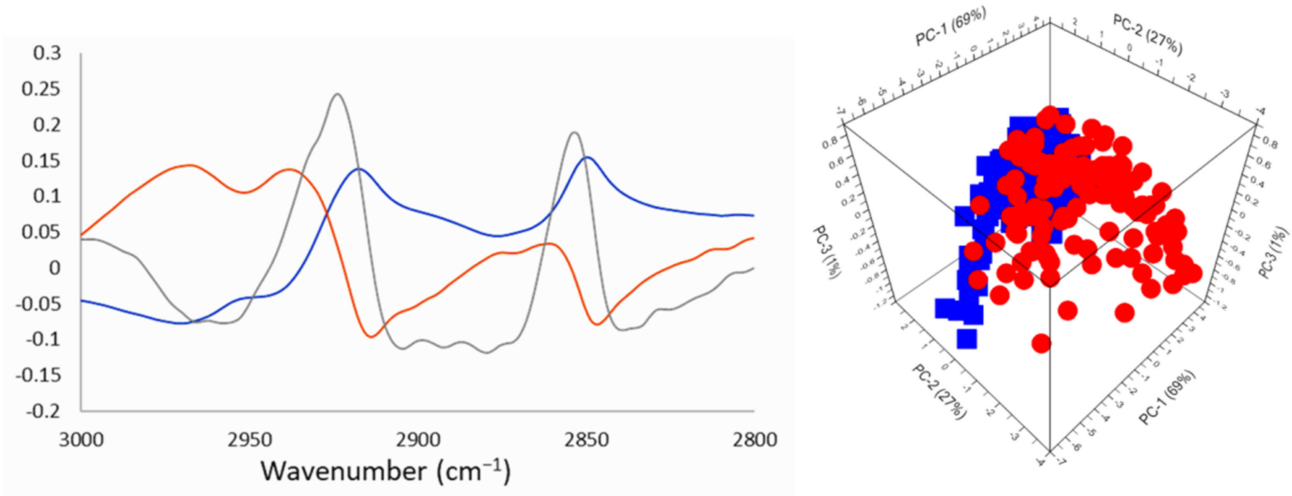

Figure 10. PCA and loadings within the lipid region $\left(3000-2800 \mathrm{~cm}^{-1}\right)$ of GICs samples treated with $\mathrm{Na}[o-\mathrm{COSAN}] 200 \mu \mathrm{M}$ : (a) GIC7 and (b) PG88 cells. Principal component loadings (blue PC-1, orange PC-2, grey PC-3) are shown on left panels. Right-panels show principal component analysis score plots of PC-1, PC-2, and PC-3 displaying the variance between GIC control cells (blue) and GIC treated cells (red).

\subsection{Na[o-COSAN] Induces DNA, Proteins, and Lipids Changes on GICs}

Since both GICs belong to non-mutated and non-G-CIMP (G-CIMP-) subtypes termed as proneural (GIC7) and mesenchymal (GP88), we explored DNA, proteins, and lipids differences between them (Figure 11a and Supplementary Table S4). SR-FTIRM microspectroscopy showed basal differences within DNA spectra, which involved $1236 \mathrm{~cm}^{-1}$ (Student's $t$-test, $p<0.0001$ ) and $949 \mathrm{~cm}^{-1}$ (Student's $t$-test, $p<0.0001$ ) peaks; $1655 \mathrm{~cm}^{-1}$ (Student's $t$-test, $p<0.0001$ ) and $1570 \mathrm{~cm}^{-1}$ (Student's $t$-test, $p<0.0001$ ) at the protein region; and $2922 \mathrm{~cm}^{-1}$ (Student's $t$-test, $p<0.0001$ ) and $2852 \mathrm{~cm}^{-1}$ (Student's $t$-test, $p<0.0001$ ) at the lipids area. These results suggested that these phenotypic differences might be involved in $\mathrm{Na}$ [o-COSAN] $\mathrm{EC}_{50}$ different responses exerted between GIC7 $(95.87 \mu \mathrm{M})$ and PG88 $(83.2 \mu \mathrm{M})$ cells. Therefore, the potential of SR-FTIRM to detect simple biochemical components might be used to stratify cells by their relative contents of lipids, glycogen, proteins, and other components, and this specific signature could predict therapy response. Indeed, ATR-FTIR spectroscopy has analytical capabilities for cancer diagnosis and is able to distinguish between healthy controls and brain cancer at sensitivities and specificities above $90 \%$, and differentiate several types of brain tumors with accuracies $>80 \%$ [68]. 
a
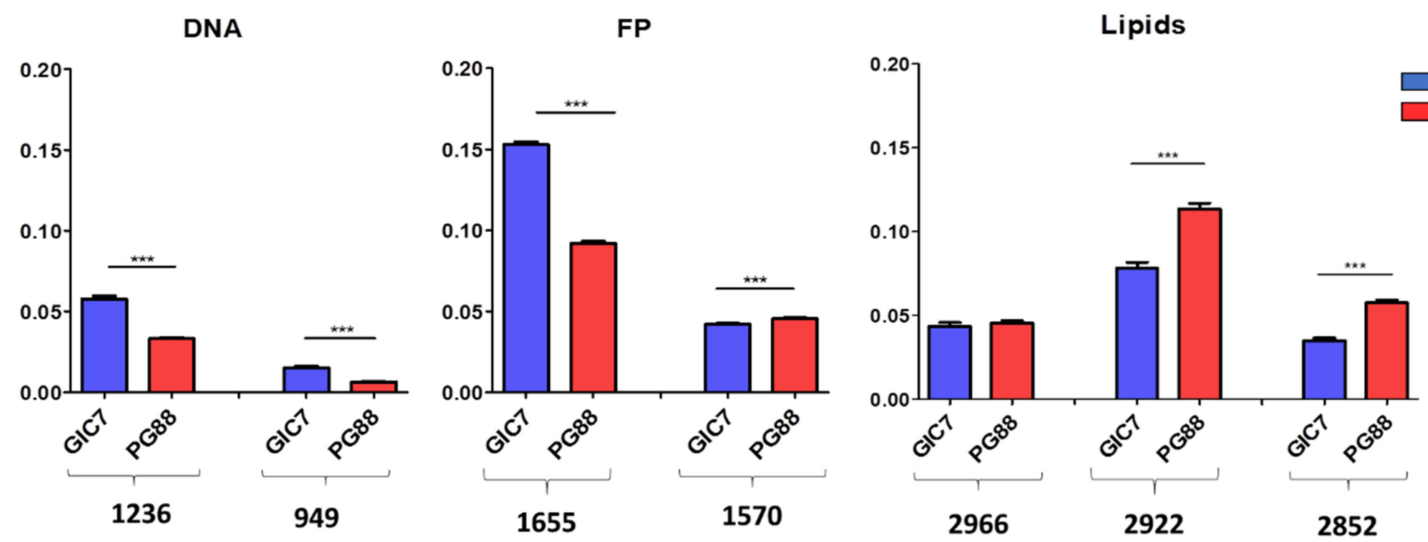

b
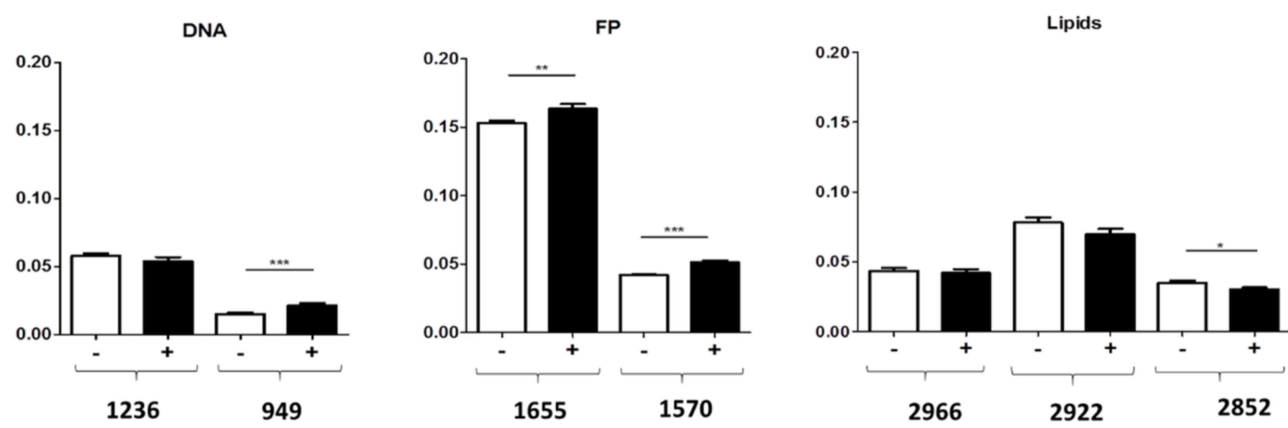

\section{GIC7 \\ Control \\ $200 \mu \mathrm{M}$}
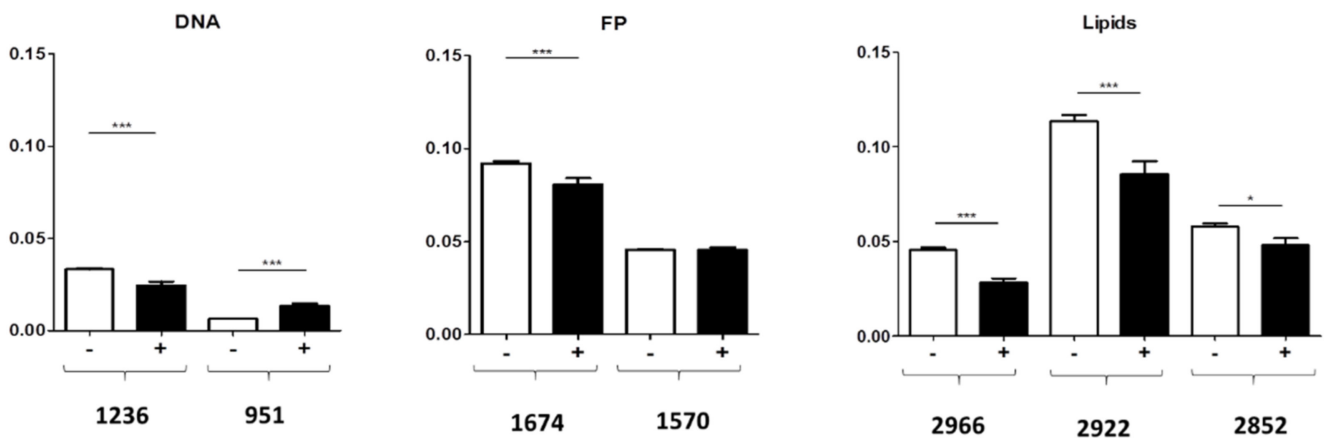

PG88

Control

$200 \mu \mathrm{M}$

Figure 11. Comparison between GIC7 and PG88 analyses by SR-FTIRM- Histogram plots are representative from DNA, protein, and lipid peaks: (a) comparison between untreated GIC7 and PG88 cells and (b) comparison between treated cells with $200 \mu \mathrm{M} \mathrm{Na}[o-C O S A N] 5 \mathrm{~h}$ with regard the respective untreated control cells (black and white columns, respectively), upper part GIC7 and PG88 at the bottom part. Significant differences by $t$-test, ${ }^{*} p<0.05 ;{ }^{* *} p<0.01 ;{ }^{* * *} p<0.001$ are pointed out at the corresponding peaks.

In addition, we analyzed by comparison spectroscopic differences between $\mathrm{Na}[\mathrm{o}-$ COSAN] treated and untreated cells and we found important changes in biomolecules in both GIC7 and PG88 cell lines (Figure 11b and Supplementary Table S5), including the proteins' secondary structure increasing the tendency to $\alpha$-helix, lipid modifications, and DNA chains, either in GIC7 or PG88 cells. Some differences appeared specifically in GIC7 or PG88 cells. Indeed, we observe that $\mathrm{Na}[0-\mathrm{COSAN}]$ induced an increase in $\beta$-sheet secondary structure of proteins in PG88 that was not observed in GIC7. 
The most significant DNA changes induced in treated GIC7 concerning untreated cells were at $949 \mathrm{~cm}^{-1}$ frequency (Student's $t$-test, $p=0.0004$ ), whereas in treated PG88 cells concerning untreated cells were at $951 \mathrm{~cm}^{-1}$ (Student's $t$-test, $p<0.0001$ ) and at $1236 \mathrm{~cm}^{-1}$ (Student's $t$-test, $p=0.0002$ ). Within proteins, the treatment increased $1655 \mathrm{~cm}^{-1}$ (Student's $t$-test, $p=0.0033$ ) and $1570 \mathrm{~cm}^{-1}$ (Student's $t$-test, $p<0.0001$ ) bands in GIC7, whereas in PG88 we did not find changes in these bands, and the one at $1674 \mathrm{~cm}^{-1}$ decreased significantly by the treatment (Student's $t$-test, $p=0.0008$ ). Moreover, lipids' changes were observed mainly in PG88 cells at $2966 \mathrm{~cm}^{-1}$ (Student's $t$-test, $p<0.0001$ ) and $2922 \mathrm{~cm}^{-1}$ (Student's $t$-test, $p=0.0008$ ) frequencies.

GBM exhibits a high degree of phenotypic heterogeneity that molecularly corresponds to different gene expression signatures. We uncover large genetic diversity in primary and recurrent aggressive glioblastomas. However, all these diverse tumors map onto a common path of early tumorigenesis where characteristic driver mutations are acquired by losses or gains of (parts of) chromosomes [69]. In that scenario, BNCT therapy in recurrent glioblastomas has emerged as a novel therapeutic strategy, since the benefit of chemotherapy, the most frequently applied treatment in this stage, has limited improvement in survival and classical radiotherapy to treat recurrences is controversial [70]. However, it has been reported that after tumor-selective $\mathrm{BNCT}$, recurrence was inevitable and hence the development of boron agents was important for the success of BNCT [71]. Herein, we have shown in two different GICs that the uptake of anionic inorganic small molecule cobaltabis(dicarbollide), $[0-\mathrm{COSAN}]^{-}$can damage essential structures of cells, mainly with the lipids compartment being the most affected.

To demonstrate the effectiveness of $[0-\mathrm{COSAN}]^{-}$to BNCT treatment is needed, more laboratory research combined with properly controlled trials investigating the in vivo assessment of the tumor-to-blood ratio and the $[0-\mathrm{COSAN}]^{-}$concentration at tumor tissue, which had to be at least three times greater than in the normal brain [72]. Moreover, we have to find out if $[o-C O S A N]^{-}$has low toxicity and both the tumor/brain and tumor/blood boron ratios are greater than 1 , as has been demonstrated in in vivo experiments for this kind of compound.

GICs, which are functionally defined by their ability to self-renew and to initiate tumor formation in vivo, are responsible for the perpetuation of the tumor and are conveniently used to perform 3D cultures systems that recapitulate the complex reality of glioblastoma better. Since there are some strict requirements before using the boron drugs for BNCT application, such as their toxicity, solubility, and dosage accumulation in the cancer cells, we are currently using normal cerebral organoids. These form smooth, 3D spheroid structures, which are a good substrate to support the invasive growth of tumor spheres by generating projections of tumor mass beyond the boundaries of the organoid combining normal and tumor cells. However, the basic knowledge about pharmacokinetics and toxicity of boron compounds has been achieved by broad study of boron carriers for BNCT that can be useful for the development of boron compounds for cancer therapy. Here we afforded the two principal requirements: $\mathrm{Na}[o-\mathrm{COSAN}]$ has a high GICs uptake without toxicity and rapid cell clearance but enough persistence to expect successful BNCT. Further work must afford the complementarity of in vitro and in vivo studies to yield significant insight into cell biological questions. Thus, in vitro culture studies and in vivo studies can be complementary, and together can yield significant insight into cell biological questions. Studies on 3D spheroids and in vivo in the small invertebrate C. elegans are undergoing and will be published as soon as possible.

\section{Materials and Methods}

\subsection{Reagents}

The $\mathrm{NaCl}$ was purchased from Sigma-Aldrich (Darmsdadt, Germany), whereas the cationic exchanging resin used (Amberlite IR120, $\mathrm{H}$ form) was purchased from Acros Organics (Geel, Belgium) and the hydrochloric acid (37\%) was purchased from Labbox (Premià de Dalt, Spain). 
RNase A (Sigma), which corresponds to a reagent of $0.02 \mathrm{mg} / \mathrm{mL}$ PI (Sigma), and $0.1 \%$ $(v / v)$ Triton X-100.

\subsection{Chemistry}

Cs $\left[3,3^{\prime}-\mathrm{Co}\left(1,2-\mathrm{C}_{2} \mathrm{~B}_{9} \mathrm{H}_{11}\right)_{2}\right], \mathrm{Cs}[o-\mathrm{COSAN}]$, was synthesized from 1,2-closo- $\mathrm{C}_{2} \mathrm{~B}_{10} \mathrm{H}_{12}$ from Katchem Spol.sro (Kralupy nad Vltavou, Czech Republic) as reported in the literature [48]. The [Na.2.5 $\left.\mathrm{H}_{2} \mathrm{O}\right]\left[3,3^{\prime}-\mathrm{Co}\left(1,2-\mathrm{C}_{2} \mathrm{~B}_{9} \mathrm{H}_{11}\right)_{2}\right], \mathrm{Na}[o-\mathrm{COSAN}]$, was obtained by means of cationic exchange resin from $\mathrm{Cs}[0-\mathrm{COSAN}]$ following the previously described procedure [73].

\subsection{Cell Culture and Treatments}

Both GICs belong to non-mutated and non-G-CIMP (G-CIMP-) subtypes. Figure 1 displays the optical microscopy images in the medium with and without laminin coated surface. GICs grow as neurospheres in non-laminin coated plates and in adherence in laminin coated surface. Cells placed on 7,5 mg/mL laminin-coated plates (Sigma, St. Louis, MO, USA) were maintained in a complete Neuronal Stem Cell (NSC) medium at $37^{\circ} \mathrm{C}$ in a humidified $5 \% \mathrm{CO}_{2}$ and $5 \% \mathrm{O}_{2}$ atmosphere (hypoxia conditions) to simulate brain microenvironment (Heracell 150i incubator). NSC medium was constituted by Dulbecco's Modified Eagle Medium and Nutrient Mixture F-12,DMEM/F12, (Gibco, Thermo Fisher Scientific, Inc., Waltham, MA, USA) supplemented with $\mathrm{N}_{2}$ (GIBCO), 4,5\% glucose (Sigma, Merck KGaA, Darmstadt, Germany), 1M Hepes (Sigma), 2\% BSA (Sigma) basic fibroblast growth factor $20 \mathrm{ng} / \mathrm{mL}$ (Gibco), and epidermal growth factor $20 \mathrm{ng} / \mathrm{mL}$ (Gibco).

GICs were treated with $200 \mu \mathrm{M}$ or $2 \mathrm{mM}$ of $\mathrm{Na}[o-\mathrm{COSAN}]$ to study the uptake of the anionic small molecule $[o-\mathrm{COSAN}]^{-}$and its effects on cell function.

Glioma initiating cells (GICs), proneural GIC7 (a kind gift from Dr. Marta María Alonso, Department of Pediatrics, Clínica Universidad de Navarra, University of Navarra, Pamplona, Spain) [74], and mesenchymal PG88 cells were obtained from human GBM specimens as described previously $[46,75]$.

\subsection{Samples Preparation for SR-FTIRM Measurements}

To analyze the interaction of the anionic small molecule $[o-\mathrm{COSAN}]^{-}$with GICs, we seeded 100,000 cells in 12-well plates, containing a glass treated $4 \mathrm{~h}$ with UV light and coated with laminin (Sigma) at 1.5\% in Dulbecco's Phosphate Buffered Saline, DPBS (Gibco). GICs were incubated for $48 \mathrm{~h}$ in $1 \mathrm{~mL}$ of fresh NSC prior to add the $\mathrm{Na}$ [o-COSAN] and incubate $5 \mathrm{~h}$ in hypoxic conditions. Next, the medium was removed and the wells washed with DPBS and fixed 20 min with $4 \%$ of PFA in PBS followed by Millipore water washes.

When cells grew on neurospheres, the wells were centrifuged at $700 \mathrm{rpm} 4 \mathrm{~min}$, washed, and disaggregated on $5 \mathrm{~mL}$ of DPBS, prior to fixing cells and placing the pellet on the $\mathrm{CaF}_{2}$ infrared windows to be analyzed.

\subsection{SR-FTIRM Measurements}

FTIRM experiments in transmission mode were performed at MIRAS beamline of ALBA synchrotron light source (Barcelona, Spain) using a Hyperion 3000 Microscope coupled to a Vertex 70 spectrometer (Bruker, Karlsruhe, Germany) and equipped with a Mercury-Cadmium-Telluride (MCT) $50 \mu \mathrm{m}$ detector. The synchrotron infrared light is focused on the sample using a $36 \times$ Schwarzschild objective $(\mathrm{NA}=0.52)$ coupled to a $36 \times$ Schwarzschild condenser. The spectra were recorded through a $10 \times 10 \mu \mathrm{m}^{2}$ masking aperture size with a spectral resolution of $4 \mathrm{~cm}^{-1}$, within the Mid-IR spectral range of $4000-800 \mathrm{~cm}^{-1}$, and a co-addition of 100 scans per spectrum to improve the signal-to-noise ratio. Background spectra were collected every 5 cell measurements from a clear area that does not contain a sample. Single cells were mapped at $3 \times 3 \mu \mathrm{m}^{2}$ resolution using $1.5 \mu \mathrm{m}$ distance between points. 


\subsection{FTIRM Software \& Data Analysis}

The OPUS 7.5 software (Bruker) was employed for data acquisition, while multivariate analysis was performed using the Unscrambler X10.3 software (CAMO Process AS, Oslo, Norway).

Prior to principal component analysis (PCA), extended multiplicative signal correction (EMSC) was applied on the raw spectra, following previous protocols [76,77]. Standard normal variate (SNV) normalization was applied in the following regions: the fingerprint $\left(1800-1000 \mathrm{~cm}^{-1}\right)$ and the lipids $\left(3000-2800 \mathrm{~cm}^{-1}\right)$ regions. Second derivative spectra were calculated using the Savitzky-Golay algorithm (third polynomial order; 9 smoothing points) for the DNA region $\left(1350-900 \mathrm{~cm}^{-1}\right)$ and unit vector normalized.

The deconvolution of the Amide I signals was made by calculating the average spectra for each sample in the Amide I region (1700-1600 $\mathrm{cm}^{-1}$ ), applying the linear baseline correction, and then the spectra were unit vector normalized. Once corrected, second derivative spectra were calculated using the Savitzky-Golay algorithm (third polynomial order; 9 smoothing points). The peaks of each protein secondary structure were assigned using the second derivative minimum values at the following values: $1610 \mathrm{~cm}^{-1}$ for sidechain, $1630 \mathrm{~cm}^{-1}$ for $\beta$-sheet, $1652 \mathrm{~cm}^{-1}$ for $\alpha$-helix, $1682 \mathrm{~cm}^{-1}$ for $\beta$-turn, and $1690 \mathrm{~cm}^{-1}$ for $\beta$-sheet antiparallel [64]. Using these wavenumbers, each peak was assigned to a Gaussian function. The parameters of each function were calculated using Solver extension of Microsoft Excel by reducing the square errors of the sum of the Gaussians with the experimental spectra.

\subsection{Kinetic Assay}

For kinetic assay, 5000 GICs were seeded in each well of a 96 multi-well plate in a complete NSC medium for $48 \mathrm{~h}$ at $37{ }^{\circ} \mathrm{C}$ in $5 \% \mathrm{CO}_{2}$ and $5 \% \mathrm{O}_{2}$ atmosphere, before incubation with $200 \mu \mathrm{M}$ of $\mathrm{Na}[0-\mathrm{COSAN}]$ in fresh NSC medium and sampling supernatant at $0 \mathrm{~min}, 15 \mathrm{~min}, 30 \mathrm{~min}, 45 \mathrm{~min}$, and $1 \mathrm{~h}$ to lyse cells in each well with $0.2 \%$ of DMSO in PBS, to evaluate $\mathrm{Na}[o-\mathrm{COSAN}]$ uptake (Figure 2a) by the spectrometer Synergy (BioTek, Agilent Technologies, Santa Clara, CA, USA) at $282 \mathrm{~nm}$. Cells with or without $\mathrm{Na}[o-\mathrm{COSAN}]$ and wells with $\mathrm{Na}[o-\mathrm{COSAN}]$ and medium without cells were used as negative and positive controls, respectively.

\subsection{PrestoBlue Assay}

PrestoBlue is a resazurin-based membrane permeable solution, which, upon reduction by living cells, forms a red fluorescent compound called resorufin via mitochondrial enzymes of viable cells in the tested systems. Consequently, the reagent exhibits a change in color, and a shift in its fluorescence, which is quantitatively measurable providing information on the cell viability. For the experiment, 5000 GICs, GIC7 and PG88, were seeded in each well of a 96 multi-well plate in complete culture medium. The cells were incubated $48 \mathrm{~h}$ at $37{ }^{\circ} \mathrm{C}$ under $5 \% \mathrm{CO}_{2}$ and $5 \% \mathrm{O}_{2}$. Next, the medium was aspirated and $\mathrm{Na}[0-\mathrm{COSAN}]$ in fresh medium was added to achieve the final tested concentrations $[\mu \mathrm{M}]$ : $50,75,100,125,150,175,200,250$, and 300, added to each well in triplicates. Control cells that contained only cells in medium without $\mathrm{Na}[o-\mathrm{COSAN}]$ were also incubated at $37^{\circ} \mathrm{C}$ under $5 \% \mathrm{CO}_{2}$ and $5 \% \mathrm{O}_{2}$ for $48 \mathrm{~h}$. Next, $10 \mu \mathrm{L}$ of PrestoBlue 10X (Life Technologies, Carlsbad, CA, USA) in $90 \mu \mathrm{L}$ of fresh NSC medium was added and incubated at $37^{\circ} \mathrm{C}$ for $2 \mathrm{~h}$. Absorbance (Abs) was recorded at wavelength of $570 \mathrm{~nm}$ and $600 \mathrm{~nm}$ by the Synergy (BioTek, Agilent Technologies). Data was normalized according to the manufacture protocol.

\subsection{Cytotoxicity and Half Maximal Effect Concentration ( $E C_{50}$ )}

Cytotoxicity and $\mathrm{EC}_{50}$ were determined by PrestoBlue assays according to Nowak et al. and Organization for Economic Cooperation and Development (OECD) protocol [78]. The absorbance of the control sample (untreated cells) represented $100 \%$ cell viability. Cell viability (\%) was calculated as follows: [(A570 sample-A570 blank)/(A570 control-A570 
blank $) \times 100$ ], and cytotoxicity $(\%)$ was determined with respect to $100 \%$ of cell viability of the control (untreated cells). The results were presented as mean \pm standard deviation (SD)/standard error of the mean (SEM) in Figure $2 b$. The value of $\mathrm{EC}_{50}$ was determined from curves according to OECD protocol.

\subsection{Cell Cycle Analysis}

Cell cycle was analyzed by flow cytometry after mark with propidium iodide (PI) the cells. GIC7 and PG88 cells were treated with $200 \mu \mathrm{M}$ and $2 \mathrm{mM}$ of $\mathrm{Na}[o-\mathrm{COSAN}]$ in complete medium for $5 \mathrm{~h}$ and after recovery $43 \mathrm{~h}$ later. Following treatment, cells were harvested, washed with PBS, and fixed with $70 \%$ ethanol at $4{ }^{\circ} \mathrm{C}$ during $2 \mathrm{~h}$. Next, the ethanol-suspended cells were centrifuged $5 \mathrm{~min}$ at $200 \mathrm{rpm}$. The ethanol was decanted thoroughly and the cell pellet was suspended in $5 \mathrm{~mL}$ PBS and centrifuged $5 \mathrm{~min}$ at $200 \mathrm{rpm}$. Finally, cell pellet was suspended in $500 \mu \mathrm{L}$ PI/Triton X-100 staining solution with RNase A $(0.02 \mathrm{mg} / \mathrm{mL}$ PI (Sigma), 0.1\% ( $v / v)$ Triton X-100 (Sigma) and 2mg DNase-free RNase A (Sigma) and incubated $15 \mathrm{~min}$ at $37^{\circ} \mathrm{C}$. Cycle analysis was performed using flow cytometry system. FlowJo software(v 10.0) was used to determine the proportions of cells in different cell stages of cell cycle progression (Sub $G_{0}, G_{0} / G_{1}, S$, and $G_{2} / M$ phases).

\subsection{Microscopic Observations of Cell Morphology}

GIC7 and PG88, GICs, 5000 cells/well seeded in 96 multi-well plates, at $37^{\circ} \mathrm{C}$ under $5 \% \mathrm{CO}_{2}$ and $5 \% \mathrm{O}_{2}$ were analyzed after the addition of $\mathrm{Na}[o-\mathrm{COSAN}] 200 \mu \mathrm{M}$ of NSC fresh medium. Cells without $\mathrm{Na}[o-\mathrm{COSAN}]$ were used as controls. Cellular morphological and density changes were observed under phase contrast microscope (Olympus) and photographed (Figure $3 a, b)$ to analyze the treated cells recovery. Photographic material was obtained before adding $\mathrm{Na}[o-\mathrm{COSAN}]$ (control with vehicle), after $5 \mathrm{~h}$ incubation with $\mathrm{Na}[o-C O S A N]$ and after incubating the previous rinsed cells during $43 \mathrm{~h}$ with fresh NSC medium.

\subsection{Statistical Analysis}

Two-tailed Student's $t$ test (to compare two experimental groups) or an ANOVA (to compare three or more groups) were performed for data analysis using GraphPad Prism (GraphPad Software). Bonferroni post-test was performed to compare replicate means. For all statistical methods, $p<0.05$ was considered significant.

\section{Conclusions}

In this work infrared micro-spectroscopy has been successfully used to detect the cellular uptake of the $\mathrm{Na}[o-\mathrm{COSAN}]$ and interactions between $[o-\mathrm{COSAN}]^{-}$and biomolecules (lipids, proteins and DNA) inside cells.

SR-FTIRM can be applied to the uptake detection of boron clusters (boranes, carboranes, and metallacarboranes) because these compounds' families display a strong and characteristic $v(\mathrm{~B}-\mathrm{H})$ frequency in the infrared range $2.600-2.500 \mathrm{~cm}^{-1}$ in which no other frequencies of organic compounds appear. The observed interactions between [o-COSAN] ${ }^{-}$ and biomolecules (lipids, proteins and DNA) that were reported on a chemical scale have been detected inside cells by means of SR-FTIRM.

The small molecule $\mathrm{Na}$ [o-COSAN], localized close to the cell's nucleus, induces proteins' conformational changes and spectral changes of the DNA region in both GIC cell lines similar to the changes induced by other metal-based compounds like cisplatin that disrupt the double helix base pairing, suggesting that $\mathrm{Na}[o-\mathrm{COSAN}]$ is a promising agent for BNCT of glioblastoma. Furthermore, our studies also show that mesenchymal PG88 cells that are more resistant than proneural GIC7 cells to conventional radiotherapy have a lower $\mathrm{EC}_{50} \mathrm{Na}$ [o-COSAN] and a higher uptake of the compound compared to GIC7 cells, suggesting a new resource to fight against resistant glioblastoma cells.

Furthermore, SR-FTIR micro-spectroscopy analysis differentiates the two phenotypes of glioma initiating cells (GICs), mesenchymal and proneural GICs, mainly by DNA spectra, 
protein conformation and lipidic components, which were differently modified by $\mathrm{Na}[\mathrm{o}-$ COSAN]. Interestingly, specific changes in lipid $2966 \mathrm{~cm}^{-1}$ and $2922 \mathrm{~cm}^{-1}$ frequencies are induced in radio resistant mesenchymal cells PG88, the most efficient in capturing the compound. Although more experiments are needed including representative GICs from glioblastoma phenotypes, these results suggest that SR-FTIRM is useful to acquire a drug and radio-resistance profiling of glioblastoma cells. Moreover, the high uptake of $\mathrm{Na}[\mathrm{o}-$ COSAN] with rapid clearance but still enough persistence is expected to allow successful BNCT application to fulfil the requirements for boron-containing agents. Although SRFTIRM is able to distinguish different subtypes of GICs, further tissue-based studies are needed to determine whether FTIR can stratify subtypes of cerebral glioma by identifying differences in DNA, proteins, and lipids molecules.

Supplementary Materials: The following are available online at https:/ / www.mdpi.com/article/10 $.3390 /$ ijms22189937/s1.

Author Contributions: Conceptualization, C.V. and À.S. with inputs from F.T. and J.J.G.; methodology, M.N.-M., L.P., I.M.-R., I.Y., D.D., E.S., F.M.-S., A.T., C.V. and Ä.S.; formal analysis, M.N.-M., L.P., D.D., I.M.-R., I.Y., C.V. and À.S.; investigation, M.N.-M., L.P., I.M.-R. and I.Y.; writing-original draft preparation, M.N.-M., L.P., C.V. and À.S.; discussions of the research, writing—review and editing, all the authors. All authors have read and agreed to the published version of the manuscript.

Funding: The authors received support from the Spanish Ministry of Health and Consumer Afairs, the ISCIII-Subdirección General de Evaluación and the Fondo Europeo de Desarrollo Regional (FEDER) FIS-PI18/00916. This work has been supported by the Spanish Ministerio de Economía y Competitividad (PID2019-106832RB-I00), the Generalitat de Catalunya (2017SGR1720) and CELLSALBA Synchroton (Ref.: 2019023533). Miquel Nuez is enrolled in the PhD program of the UAB.

Institutional Review Board Statement: Not applicable.

Informed Consent Statement: Not applicable.

Data Availability Statement: Not applicable.

Acknowledgments: I.M.-R. acknowledges the financial support from the Spanish Ministry of Science, Innovation and Universities (fellowship RYC2018-024043-I). L.P. and D.D. acknowledges AECC (Spanish Association Against Cancer. Project GCTRA16015SEDA). L.P., A.S. and J.J.G. thanks Dr. Marta María Alonso, Department of Pediatrics, University of Navarra for the kind gifts of Glioma initiating cells (GICs) proneural GIC7.

Conflicts of Interest: The authors declare no conflict of interest.

\section{References}

1. Stupp, R.; Mason, W.P.; Van den Bent, M.J.; Weller, M.; Fisher, B.; Taphoorn, M.J.B.; Belanger, K.; Brandes, A.A.; Marosi, C.; Bogdahn, U.; et al. Radiotherapy plus concomitant and adjuvant temozolomide for glioblastoma. N. Engl. J. Med. 2005, 352, 987-996. [CrossRef]

2. Ohka, F.; Natsume, A.; Wakabayashi, T. Current trends in targeted therapies for glioblastoma multiforme. Neurol. Res. Int. 2012, 2012, 878425. [CrossRef] [PubMed]

3. Goellner, E.M.; Grimme, B.; Brown, A.R.; Lin, Y.-C.; Wang, X.-H.; Sugrue, K.F.; Mitchell, L.; Trivedi, R.N.; Tang, J.-B.; Sobol, R.W. Overcoming temozolomide resistance in glioblastoma via dual inhibition of NAD+ biosynthesis and base excision repair. Cancer Res. 2011, 71, 2308-2317. [CrossRef] [PubMed]

4. Moreno, M.; Pedrosa, L.; Pare, L.; Pineda, E.; Bejarano, L.; Martínez, J.; Balasubramaniyan, V.; Ezhilarasan, R.; Kallarackal, N.; Kim, S.-H.; et al. GPR56/ADGRG1 inhibits mesenchymal differentiation and radioresistance in glioblastoma. Cell Rep. 2017, 21, 2183-2197. [CrossRef] [PubMed]

5. Singh, S.K.; Hawkins, C.; Clarke, I.D.; Squire, J.A.; Bayani, J.; Hide, T.; Henkelman, R.M.; Cusimano, M.D.; Dirks, P.B. Identification of human brain tumour initiating cells. Nature 2004, 432, 396-401. [CrossRef]

6. Lee, J.; Kotliarova, S.; Kotliarov, Y.; Li, A.; Su, Q.; Donin, N.M.; Pastorino, S.; Purow, B.W.; Christopher, N.; Zhang, W.; et al. Tumor stem cells derived from glioblastomas cultured in bFGF and EGF more closely mirror the phenotype and genotype of primary tumors than do serum-cultured cell lines. Cancer Cell 2006, 9, 391-403. [CrossRef] [PubMed]

7. Gimple, R.C.; Bhargava, S.; Dixit, D.; Rich, J.N. Glioblastoma stem cells: Lessons from the tumor hierarchy in a lethal cancer. Genes Dev. 2019, 33, 591-609. [CrossRef] 
8. Noushmehr, H.; Weisenberger, D.J.; Diefes, K.; Phillips, H.S.; Pujara, K.; Berman, B.P.; Pan, F.; Pelloski, C.E.; Sulman, E.P.; Bhat, K.P.; et al. Identification of a CpG island methylator phenotype that defines a distinct subgroup of glioma. Cancer Cell 2010, 17, 510-522. [CrossRef]

9. Verhaak, R.G.W.; Hoadley, K.A.; Purdom, E.; Wang, V.; Qi, Y.; Wilkerson, M.D.; Miller, C.R.; Ding, L.; Golub, T.; Mesirov, J.P.; et al. Integrated genomic analysis identifies clinically relevant subtypes of glioblastoma characterized by abnormalities in PDGFRA, IDH1, EGFR, and NF1. Cancer Cell 2010, 17, 98-110. [CrossRef] [PubMed]

10. Wang, Q.; Hu, B.; Hu, X.; Kim, H.; Squatrito, M.; Scarpace, L.; Decarvalho, A.C.; Lyu, S.; Li, P.; Li, Y.; et al. Tumor evolution of glioma-intrinsic gene expression subtypes associates with immunological changes in the microenvironment. Cancer Cell 2017, 32, 42-56. [CrossRef]

11. Phillips, H.S.; Kharbanda, S.; Chen, R.; Forrest, W.F.; Soriano, R.H.; Wu, T.D.; Misra, A.; Nigro, J.M.; Colman, H.; Soroceanu, L.; et al. Molecular subclasses of high-grade glioma predict prognosis, delineate a pattern of disease progression, and resemble stages in neurogenesis. Cancer Cell 2006, 9, 157-173. [CrossRef]

12. Piao, Y.; Liang, J.; Holmes, L.; Henry, V.; Sulman, E.; De Groot, J.F. Acquired resistance to anti-VEGF therapy in glioblastoma is associated with a mesenchymal transition. Clin. Cancer Res. 2013, 19, 4392-4403. [CrossRef]

13. Sauerwein, W.; Sancey, L.; Hey-Hawkins, E.; Kellert, M.; Panza, L.; Imperio, D.; Balcerzyk, M.; Rizzo, G.; Scalco, E.; Herrmann, K.; et al. Theranostics in boron neutron capture therapy. Life 2021, 11, 330. [CrossRef] [PubMed]

14. Miyatake, S.-I.; Kawabata, S.; Yokoyama, K.; Kuroiwa, T.; Michiue, H.; Sakurai, Y.; Kumada, H.; Suzuki, M.; Maruhashi, A.; Kirihata, M.; et al. Survival benefit of boron neutron capture therapy for recurrent malignant gliomas. J. Neuro Oncol. 2009, 91, 199-206. [CrossRef] [PubMed]

15. Barth, R.F.; Grecula, J.C. Boron neutron capture therapy at the crossroads-Where do we go from here? Appl. Radiat. Isot. 2020, 160, 109029. [CrossRef]

16. Barth, R.F.; Zhang, Z.; Liu, T. A realistic appraisal of boron neutron capture therapy as a cancer treatment modality. Cancer Commun. 2018, 38, 36-37. [CrossRef] [PubMed]

17. Barth, R.F.; Mi, P.; Yang, W. Boron delivery agents for neutron capture therapy of cancer. Cancer Commun. 2018, 38, 35. [CrossRef]

18. Teixeira, R.G.; Marques, F.; Robalo, M.P.; Fontrodona, X.; Garcia, M.H.; Crich, S.G.; Viñas, C.; Valente, A. Ruthenium carboranyl complexes with 2,2'-bipyridine derivatives for potential bimodal therapy application. RSC Adv. 2020, 10, 16266-16276. [CrossRef]

19. Armstrong, A.F.; Valliant, J.F. The bioinorganic and medicinal chemistry of carboranes: From new drug discovery to molecular imaging and therapy. Dalton Trans. 2007, 4240-4251. [CrossRef]

20. Jelliss, P.A.; Mason, J.; Nazzoli, J.M.; Orlando, A.J.H.; Vinson, A.; Rath, N.P.; Shaw, M. Synthesis and characterization of ruthenacarborane complexes incorporating chelating N-donor ligands: Unexpected luminescence from the complex [3-CO-3,3\{k2-Me2N (CH2) 2NMe2\}-closo-3,1,2-RuC2B9H11]. Inorg. Chem. 2006, 45, 370-385. [CrossRef] [PubMed]

21. Kellert, M.; Sárosi, I.; Rajaratnam, R.; Meggers, E.; Lönnecke, P.; Hey-Hawkins, E. Ruthenacarborane-phenanthroline derivatives as potential metallodrugs. Molecules 2020, 25, 2322. [CrossRef] [PubMed]

22. Couto, M.; García, M.; Alamón, C.; Cabrera, M.; Cabral, P.; Merlino, A.; Teixidor, F.; Cerecetto, H.E.; Viñas, C. Discovery of potent EGFR inhibitors through the incorporation of a 3D-aromatic-boron-rich-cluster into the 4-anilinoquinazoline scaffold: Potential drugs for glioma treatment. Chem. A Eur. J. 2018, 24, 3122-3126. [CrossRef] [PubMed]

23. Couto, M.; Alamón, C.; Sánchez, C.; Dávila, B.; Fernández, M.; Lecot, N.; Cabral, P.; Teixidor, F.; Viñas, C.; Cerecetto, H. Carboranylanilinoquinazoline EGFR-inhibitors: Toward 'lead-to-candidate' stage in the drug-development pipeline. Futur. Med. Chem. 2019, 11, 2273-2285. [CrossRef] [PubMed]

24. Grimes, R.N. Carboranes; Elsevier: New York, NY, USA, 2016.

25. Masalles, C.; Llop, J.; Viñas, C.; Teixidor, F. Extraordinary overoxidation resistance increase in self-doped polypyrroles by using non-conventional low charge-density anions. Adv. Mater. 2002, 14, 826-829. [CrossRef]

26. Hardie, M.J.; Raston, C.L. Solid state supramolecular assemblies of charged supermolecules (Na [2.2.2] cryptate)+ and anionic carboranes with host cyclotriveratrylene. Chem. Commun. 2001, 2, 905-906. [CrossRef]

27. Fox, M.A.; Hughes, A.K. Cage $\mathrm{C} \square \mathrm{H} \cdots \mathrm{X}$ interactions in solid-state structures of icosahedral carboranes. Coord. Chem. Rev. 2004, 248, 457-476. [CrossRef]

28. Brusselle, D.; Bauduin, P.; Girard, L.L.C.M.; Zaulet, A.; Viñas, C.; Teixidor, F.; Ly, I.; Diat, O. Lyotropic lamellar phase formed from monolayered $\theta$-shaped carborane-cage amphiphiles. Angew. Chem. Int. Ed. 2013, 52, 12114-12118. [CrossRef]

29. Tarrés, M.; Viñas, C.; González-Cardoso, P.; Hänninen, M.M.; Sillanpää, R.; Ďord'ovič, V.; Uchman, M.; Teixidor, F.; Matějičček, P. Aqueous self-assembly and cation selectivity of cobaltabisdicarbollide dianionic dumbbells. Chem. A Eur. J. 2014, 20, 6786-6794. [CrossRef]

30. Bauduin, P.; Prevost, S.; Farràs, P.; Teixidor, F.; Diat, O.; Zemb, T. A Theta-shaped amphiphilic cobaltabisdicarbollide anion: Transition from monolayer vesicles to micelles. Angew. Chem. Int. Ed. 2011, 50, 5298-5300. [CrossRef]

31. Viñas, C.; Tarrés, M.; González-Cardoso, P.; Farràs, P.; Bauduin, P.; Teixidor, F. Surfactant behaviour of metallacarboranes. A study based on the electrolysis of water. Dalton Trans. 2014, 43, 5062-5068. [CrossRef]

32. Ďordovič, V.; Tošner, Z.; Uchman, M.M.; Zhigunov, A.; Reza, M.; Ruokolainen, J.; Pramanik, G.; Cígler, P.; Kalíková, K.; Gradzielski, M.; et al. Stealth amphiphiles: Self-assembly of polyhedral boron clusters. Langmuir 2016, 32, 6713-6722. [CrossRef]

33. Uchman, M.; Ďord'ovič, V.; Tošner, Z.; Matějíček, P. Classical amphiphilic behavior of nonclassical amphiphiles: A comparison of metallacarborane self-assembly with SDS micellization. Angew. Chem. Int. Ed. 2015, 54, 14113-14117. [CrossRef] 
34. Liu, K.-Z.; Xu, M.; Scott, D.A. Biomolecular characterisation of leucocytes by infrared spectroscopy. Br. J. Haematol. 2007, 136, 713-722. [CrossRef] [PubMed]

35. Miller, L.M.; Dumas, P. Chemical imaging of biological tissue with synchrotron infrared light. Biochim. Biophys. Acta (BBA) Biomembr. 2006, 1758, 846-857. [CrossRef] [PubMed]

36. Dumas, P.; Tobin, M.J. A bright source for infrared microspectroscopy: Synchrotron radiation. Spectrosc. Eur. 2003, 15, 17-23.

37. Duncan, W.D.; Williams, G.P. Infrared synchrotron radiation from electron storage rings. Appl. Opt. 1983, 22, 2914-2923. [CrossRef]

38. Reffner, J.A.; Martoglio, P.A.; Williams, G.P. Fourier transform infrared microscopical analysis with synchrotron radiation: The microscope optics and system performance (invited). Rev. Sci. Instrum. 1995, 66, 1298-1302. [CrossRef]

39. Carr, G.L. Resolution limits for infrared microspectroscopy explored with synchrotron radiation. Rev. Sci. Instrum. 2001, 72, 1613-1619. [CrossRef]

40. Romeo, M.; Mohlenhoff, B.; Jennings, M.; Diem, M. Infrared micro-spectroscopic studies of epithelial cells. Biochim. Biophys. Acta (BBA) Biomembr. 2006, 1758, 915-922. [CrossRef]

41. Boydston-White, S.; Romeo, M.; Chernenko, T.; Regina, A.; Miljković, M.; Diem, M. Cell-cycle-dependent variations in FTIR micro-spectra of single proliferating HeLa cells: Principal component and artificial neural network analysis. Biochim. Biophys. Acta (BBA) Biomembr. 2006, 1758, 908-914. [CrossRef] [PubMed]

42. Merhi, T.; Jonchère, A.; Girard, L.; Diat, O.; Nuez, M.; Viñas, C.; Bauduin, P. Highlights on the binding of cobalta-bis-(dicarbollide) with glucose units. Chem. A Eur. J. 2020, 26, 13935-13947. [CrossRef]

43. Gasper, R.; Dewelle, J.; Kiss, R.; Mijatovic, T.; Goormaghtigh, E. IR spectroscopy as a new tool for evidencing antitumor drug signatures. Biochim. Biophys. Acta (BBA) Biomembr. 2009, 1788, 1263-1270. [CrossRef]

44. Rojo, I.; Teixidor, F.; Viñas, C.; Kivekäs, R.; Sillanpää, R. Relevance of the electronegativity of boron inๆ5-coordinating ligands: Regioselective monoalkylation and monoarylation in cobaltabisdicarbollide [3,3'-Co (1,2-C2B9H11) 2]-clusters. Chem. A Eur. J. 2003, 9, 4311-4323. [CrossRef]

45. Fuentes, I.; García-Mendiola, T.; Sato, S.; Pita, M.; Nakamura, H.; Lorenzo, E.; Teixidor, F.; Marques, F.; Viñas, C. Metallacarboranes on the road to anticancer therapies: Cellular uptake, DNA interaction, and biological evaluation of cobaltabisdicarbollide [COSAN]-. Chem. A Eur. J. 2018, 24, 17239-17254. [CrossRef] [PubMed]

46. Stanzani, E.; Martínez-Soler, F.; Mateos, T.M.; Vidal, N.; Villanueva, A.; Pujana, M.A.; Serra-Musach, J.; de la Iglesia, N.; GiménezBonafé, P.; Tortosa, A. Radioresistance of mesenchymal glioblastoma initiating cells correlates with patient outcome and is associated with activation of inflammatory program. Oncotarget 2017, 8, 73640-73653. [CrossRef]

47. Mátel, L'; Macášek, F.; Rajec, P.; Heřmánek, S.; Plešek, J. B-Halogen derivatives of the bis (1,2-dicarbollyl) cobalt (III) anion. Polyhedron 1982, 1, 511-519. [CrossRef]

48. Hawthorne, M.F.; Young, D.C.; Andrews, T.D.; Howe, D.V.; Pilling, R.L.; Pitts, A.D.; Reintjes, M.; Warren, L.F.; Wegner, P.A. pi.-Dicarbollyl derivatives of the transition metals. Metallocene analogs. J. Am. Chem. Soc. 1968, 90, 879-896. [CrossRef]

49. Minata, M.; Audia, A.; Shi, J.; Lu, S.; Bernstock, J.; Pavlyukov, M.S.; Das, A.; Kim, S.-H.; Shin, Y.J.; Lee, Y.; et al. Phenotypic plasticity of invasive edge glioma stem-like cells in response to ionizing radiation. Cell Rep. 2019, 26, 1893-1905.e7. [CrossRef] [PubMed]

50. Tarrés, M.; Canetta, E.; Paul, E.; Forbes, J.; Azzouni, K.; Viñas, C.; Teixidor, F.; Harwood, A.J. Biological interaction of living cells with COSAN-based synthetic vesicles. Sci. Rep. 2015, 5, 7804. [CrossRef]

51. Plesek, J. Potential applications of the boron cluster compounds. Chem. Rev. 1992, 92, 269-278. [CrossRef]

52. Tarrés, M.; Canetta, E.; Viñas, C.; Teixidor, F.; Harwood, A.J. Imaging in living cells using vB-H Raman spectroscopy: Monitoring COSAN uptake. Chem. Commun. 2014, 50, 3370-3372. [CrossRef]

53. Verdiá-Báguena, C.; Alcaraz, A.; Aguilella, V.M.; Cioran, A.M.; Tachikawa, S.; Nakamura, H.; Teixidor, F.; Viñas, C. Amphiphilic COSAN and I2-COSAN crossing synthetic lipid membranes: Planar bilayers and liposomes. Chem. Commun. 2014, 50, 6700-6703. [CrossRef]

54. Ding, L.; Cao, J.; Lin, W.; Chen, H.; Xiong, X.; Ao, H.; Yu, M.; Lin, J.; Cui, Q. The roles of cyclin-dependent kinases in cell-cycle progression and therapeutic strategies in human breast cancer. Int. J. Mol. Sci. 2020, 21, 1960. [CrossRef]

55. German, M.; Hammiche, A.; Ragavan, N.; Tobin, M.; Cooper, L.J.; Matanhelia, S.S.; Hindley, A.C.; Nicholson, C.M.; Fullwood, N.J.; Pollock, H.M.; et al. Infrared spectroscopy with multivariate analysis potentially facilitates the segregation of different types of prostate cell. Biophys. J. 2006, 90, 3783-3795. [CrossRef] [PubMed]

56. Fleming, I.; Williams, D. Infrared and raman spectra. In Spectroscopic Methods in Organic Chemistry, 7th ed.; Springer International Publishing: Cham, Switzerland, 2019; pp. 85-122. ISBN 9783030182526.

57. Kelly, J.G.; Martin-Hirsch, P.L.; Martin, F.L. Discrimination of base differences in oligonucleotides using mid-infrared spectroscopy and multivariate analysis. Anal. Chem. 2009, 81, 5314-5319. [CrossRef]

58. Kong, D.; Peng, W.; Zong, R.; Cui, G.; Yu, X. Morphological and biochemical properties of human astrocytes, microglia, glioma, and glioblastoma cells using fourier transform infrared spectroscopy. Med Sci. Monit. 2020, 26, e925754. [CrossRef] [PubMed]

59. Tagliazucchi, M.; Peleg, O.; Kröger, M.; Rabin, Y.; Szleifer, I. Effect of charge, hydrophobicity, and sequence of nucleoporins on the translocation of model particles through the nuclear pore complex. Proc. Natl. Acad. Sci. USA 2013, 110, 3363-3368. [CrossRef]

60. Gabel, D.; Foster, S.; Fairchild, R.G. The Monte Carlo simulation of the biological effect of the $10 \mathrm{~B}(\mathrm{n}, \alpha) 7 \mathrm{Li}$ reaction in cells and tissue and its implication for boron neutron capture therapy. Radiat. Res. 1987, 111, 14-25. [CrossRef] 
61. Marques, M.P.M.; Gianolio, D.; Cibin, G.; Tomkinson, J.; Parker, S.; Valero, R.; Lopes, R.P.; De Carvalho, L.A.E.B. A molecular view of cisplatin's mode of action: Interplay with DNA bases and acquired resistance. Phys. Chem. Chem. Phys. 2015, 17, 5155-5171. [CrossRef]

62. Mendiola, T.G.; Bayon-Pizarro, V.; Zaulet, A.; Fuentes, I.; Pariente, F.; Teixidor, F.; Viñas, C.; Lorenzo, E. Metallacarboranes as tunable redox potential electrochemical indicators for screening of gene mutation. Chem. Sci. 2016, 7, 5786-5797. [CrossRef] [PubMed]

63. De Carvalho, A.L.M.B.; Mamede, A.P.; Dopplapudi, A.; Sakai, V.G.; Doherty, J.; Frogley, M.; Cinque, G.; Gardner, P.; Gianolio, D.; de Carvalho, L.A.E.B.; et al. Anticancer drug impact on DNA-A study by neutron spectroscopy coupled with synchrotron-based FTIR and EXAFS. Phys. Chem. Chem. Phys. 2019, 21, 4162-4175. [CrossRef] [PubMed]

64. Ghimire, H.; Venkataramani, M.; Bian, Z.; Liu, Y.; Perera, A.G.U. ATR-FTIR spectral discrimination between normal and tumorous mouse models of lymphoma and melanoma from serum samples. Sci. Rep. 2017, 7, 16993. [CrossRef]

65. Fuentes, I.; Pujols, J.; Viñas, C.; Ventura, S.; Teixidor, F. Dual binding mode of metallacarborane produces a robust shield on proteins. Chem. A Eur. J. 2019, 25, 12820-12829. [CrossRef]

66. Ishida, K.P.; Griffiths, P.R. Comparison of the amide I/II intensity ratio of solution and solid-state proteins sampled by transmission, attenuated total reflectance, and diffuse reflectance spectrometry. Appl. Spectrosc. 1993, 47, 584-589. [CrossRef]

67. Cigler, P.; Kožíšek, M.; Řezáčová, P.; Brynda, J.; Otwinowski, Z.; Pokorna, J.; Kožíšek, M.; Gruner, B.; Dolečková-Marešová, L.; Máša, M.; et al. From nonpeptide toward noncarbon protease inhibitors: Metallacarboranes as specific and potent inhibitors of HIV protease. Proc. Natl. Acad. Sci. USA 2005, 102, 15394-15399. [CrossRef]

68. Cameron, J.M.; Rinaldi, C.; Butler, H.J.; Hegarty, M.G.; Brennan, P.M.; Jenkinson, M.D.; Syed, K.; Ashton, K.M.; Dawson, T.P.; Palmer, D.S.; et al. Stratifying brain tumour histological sub-types: The application of ATR-FTIR serum spectroscopy in secondary care. Cancers 2020, 12, 1710. [CrossRef]

69. Körber, V.; Yang, J.; Barah, P.; Wu, Y.; Stichel, D.; Gu, Z.; Fletcher, M.N.C.; Jones, D.; Hentschel, B.; Lamszus, K.; et al. Evolutionary trajectories of IDHWT glioblastomas reveal a common path of early tumorigenesis instigated years ahead of initial diagnosis. Cancer Cell 2019, 35, 692-704. [CrossRef]

70. Shiba, H.; Takeuchi, K.; Hiramatsu, R.; Furuse, M.; Nonoguchi, N.; Kawabata, S.; Kuroiwa, T.; Kondo, N.; Sakurai, Y.; Suzuki, M.; et al. Boron neutron capture therapy combined with early successive bevacizumab treatments for recurrent malignant gliomas- $\mathrm{A}$ pilot study. Neurol. Medico. Chir. 2018, 58, 487-494. [CrossRef] [PubMed]

71. Kondo, N.; Hikida, M.; Nakada, M.; Sakurai, Y.; Hirata, E.; Takeno, S.; Suzuki, M. Glioma stem-like cells can be targeted in boron neutron capture therapy with boronophenylalanine. Cancers 2020, 12, 3040. [CrossRef] [PubMed]

72. Nakahara, Y.; Ito, H.; Masuoka, J.; Abe, T. Boron neutron capture therapy and photodynamic therapy for high-grade meningiomas. Cancers 2020, 12, 1334. [CrossRef] [PubMed]

73. Zaulet, A.; Teixidor, F.; Bauduin, P.; Diat, O.; Hirva, P.; Ofori, A.; Viñas, C. Deciphering the role of the cation in anionic cobaltabisdicarbollide clusters. J. Organomet. Chem. 2018, 865, 214-225. [CrossRef]

74. Alonso, M.M.; Diez-Valle, R.; Manterola, L.; Rubio, A.; Liu, D.; Cortes-Santiago, N.; Urquiza, L.; Jauregi, P.; De Munain, A.L.; Sampron, N.; et al. Genetic and epigenetic modifications of sox2 contribute to the invasive phenotype of malignant gliomas. PLoS ONE 2011, 6, e26740. [CrossRef] [PubMed]

75. Galli, R.; Binda, E.; Orfanelli, U.; Cipelletti, B.; Gritti, A.; De Vitis, S.; Fiocco, R.; Foroni, C.; DiMeco, F.; Vescovi, A. Isolation and characterization of umorigenic, stem-like neural precursors from human glioblastoma. Cancer Res. 2004, 64, 7011-7021. [CrossRef] [PubMed]

76. Yousef, I.; Seksek, O.; Gil, S.; Prezado, Y.; Sulé-Suso, J.; Martínez-Rovira, I. Study of the biochemical effects induced by X-ray irradiations in combination with gadolinium nanoparticles in F98 glioma cells: First FTIR studies at the Emira laboratory of the SESAME synchrotron. Analyst 2016, 141, 2238-2249. [CrossRef]

77. Martínez-Rovira, I.; Seksek, O.; Dokic, I.; Brons, S.; Abdollahi, A.; Yousef, I. Study of the intracellular nanoparticle-based radiosensitization mechanisms in F98 glioma cells treated with charged particle therapy through synchrotron-based infrared microspectroscopy. Analyst 2020, 145, 2345-2356. [CrossRef] [PubMed]

78. Nowak, A.; Bakuła, T.; Matusiak, K.; Gałęcki, R.; Borowski, S.; Gutarowska, B. Odorous compounds from poultry manure induce DNA damage, nuclear changes, and decrease cell membrane integrity in chicken liver hepatocellular carcinoma cells. Int. J. Environ. Res. Public Health 2017, 14, 933. [CrossRef] 